\title{
STUDIES ON MECHANISM OF LABYRINTHINE FLUID PRODUCTION
}

\author{
By \\ K. TUBOI
}

From the Department of Oto-Rhino-Laryngology, Nagoya University school of Medicine (Director: Prof. S. Goto)

Using radio-active isotope ( $\mathrm{P} 32, \mathrm{Na} 24)$ tracer work was carried outand physiology of production of labyrinthine fluid secretion was studied.

Consequently it became obvious that endolymph and perilymph were separately, produced endo. lymph was mainly from stria vascularis, and perilymph was from spinal fluid and perilymphatic space.

\section{内耳液生成の機転についての研究 (Isotope 利用による)}

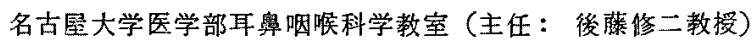

坪贲帮 夫

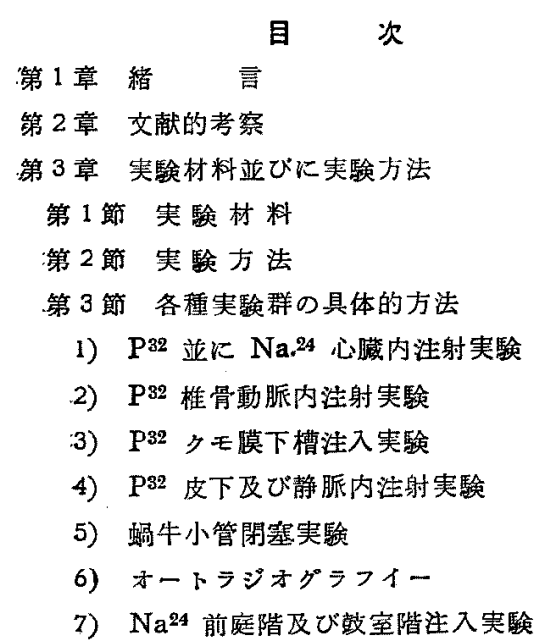

第 4 章 実験 成踹

第 1 節 $P^{32}$ に上る追跡实駼

1) $P^{32}$ 心䁍内注射例

2) $\mathrm{P}^{32}$ 椎骨動脈内注射

3) $\mathrm{P}^{32}$ 例クモ膜下橧泩入例

4） P 32 皮下及び静脈内泩射例

5）蝸牛小管閉塞実験例

第 2 節 P $\mathrm{P}^{32}$ によるオートフジオグラフイー

第 3 節 $\mathrm{Na}^{24}$ 辰上省追跡实験

1) $\mathrm{Na}^{24}$ 心朦内注射例
2) $\mathrm{Na}^{24}$ 䟾室階及び前庭階注入例

第 5 章 総括並汇考按

第6 章 結 論

文献

\section{第 1 章 緒产}

音波の聴覚受容器への伝達は内耳液といら一つの媒筫 を通じて行われ，内耳液無くしては聴覚機構の成立は不 可能であり，この点より見ても内耳液の重要性は明らか

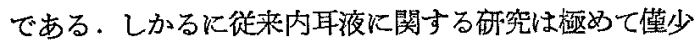
であり，聴覚障害との関連性に就いては，昭和 27 年後 䔉教授》の宿題報告中に和いて「内耳液疾患の提唱」と して始好明かにされたところであるが，聴當挛害時に

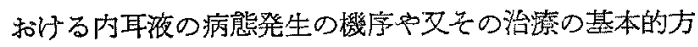
針を勘案するに必要な基磷的生理学の解明はな和不十分 であり，内耳液の起源並に先の運命に就いても未济定説 がない現状である。これは主としてその研究方法論上の 誤謬乃至は困難性にもとづくものであり，これ等は推測 器具の発達と各和愦謬の反省によつて次第に真実に近つ くものと考兄ら机る。

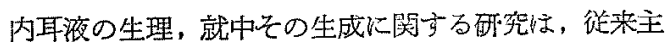
として色素を用いを組織学的のものであるが，色菜顆粒 の大きさ，透過性又は比重の点，及び異物としての作用 等を考えるとき真の生成生理の追及には不渵足であり， 極言すれば非生理的な状況の観察とも云い得るむのであ 
り，又蛋白質に乏しい内耳液の固定の困難性はこの判定 を更に困難なるのにしたのでする，一方組繩学的方法に よらない追究の方法としては種々の菂液, 色素液等を注 入した後に括ける内耳液の観察が試双られているが，か 、万方法を用いたものには内，外曰ンパの別個の観察か 行われたものは少なく，又行わんとしても一つの経路の みでなく他の経路を経たものと区别することが難く、そ の判定には正确を期し難い，斯くの如くその方法論上の

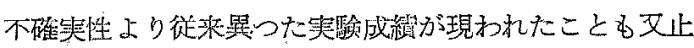
さを得ない。

こっに执いて秘该来種々の難点を有した内耳液生成 生理の研究に放射性同位元䐂を tracer としての耾究を 行つた.

こして本編に和いても正常状態下の動物に $\mathrm{P}^{32}$ 並に $\mathrm{Na}^{24}$ を用いて内, 外》ンパの生成に関して研索した成 䁚について述べんとするものである。

\section{第 2 章 文献 的考察}

私の実験について述べるに先立つて，従来いかなる説 が提示されてきたかを整理してこつに記さんとする。こ れは特に異説の多いこの方面の哳究に考察を及ぼさんと

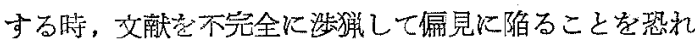
たがらである。

占く源を溯れば1683 年 Du Verney 2)か螖牛小管を 認妨，これより内耳に動，静脈を送りこむことを発表 し, Valsalva 2) (1707) が迷路内にリンパ夜の存在を認 め, Pacchioni 2) (1727) が骨亩液の阳耳への流大を発表 乙て以来, 内耳液の生成, 㖧環, 吸收等についての矿究 が次第に活発になつたのである.

1了先ず外リンパの生成，循環等について見る㭙， これ认關する詵は

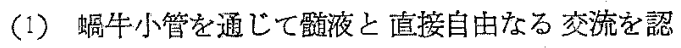
め説

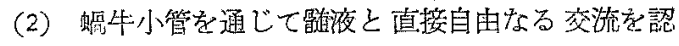
ぬない説

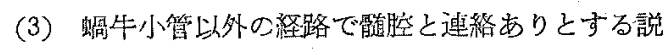

(4) 外りンバ腔自身で外リンパの坐産を認める説

(5)内リンパ电来するといら説

に大別できる。

（1）螖牛小管を通じて䯣液と直接交通を認める説 これは解剖学的にも最む容易に考えられる説であり， 㕛この説の支持者は極めて多いのである．即ら Contugno 3) (1774) は外リンパほ蜩它小管を通じて頭蓋腔に 移行していると報告し，Hirt13)（1860）は阿麻仁淄をタ
モ膜下槽に注入してとの交通路として螖牛小管を挙げ， これを通じて髄液が外ッンハ腔に到造すると述べ，Hasse (1881) は外リンバの大部分は外リンパ管炎通し て,クモ膜下腔と交道すると言い, Webel-Liel4) (1879) はベルリン青を用いた実験からして外りンパは蜩牛小管 を通じてクモ㮠下腔と交通していると報告した。

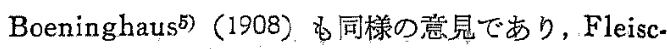
hmann ${ }^{6)}$ (1918) 6色集奏験の成續からして一般に内耳

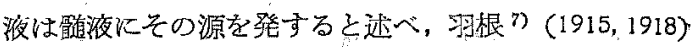
はとの起源については触てていないが内耳液の血清学的 研究から觼液と内耳液とは相似たものであると述べ，木

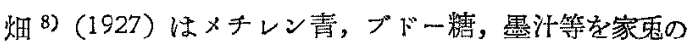
クモ膜下腔に注入し，該物質が蝸牛小管を通つて外リン ハ腔に達するのを組絊学的に証明し，内耳液は髄液と直 接且つ自由な交流があり，その主なる通路は福牛小管で あり，内耳液は檤液に由来するとした，同様に田中み

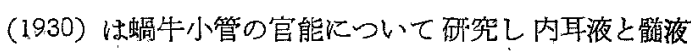
との通過性を色素実験より誋め，Karbowski10) (1930),

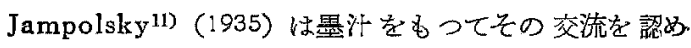

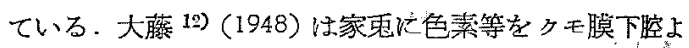
り注入して外リンハ腔に流入させ，あるいは逆に流入さ せて嗔液は蛤牛小管を経て自由に外リンパと連絡するこ とを報告し，更に氏 ${ }^{13)} 1951$ 年には人胎児及び成人屍

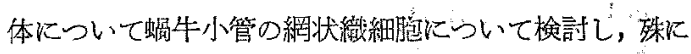
その開口部《称いて胎奣の過半数に特殊の Barrier me. mbrane の存在を認めるが鼓室階外リンパはこの分離膜

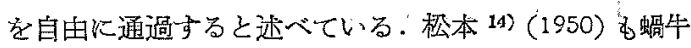
小管内部組䋨が後頭下注入のカルミン焦素をよく盆哈す ることからこれは所謂網状繵内被細胞柔統に属し，WaItner (後述) の言らが如き特殊のBrrier membrane は

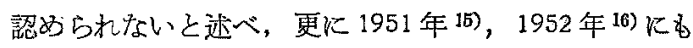
続いて実跧的結果を発紊し，タモ膜下腔に注入した墨汁

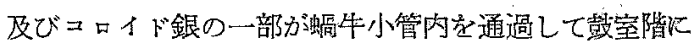
達したのを見て，螖牛小管の通過性を証明し，注入物質 の蝸牛小管内存在部位か゚主として「ッンパンホル」で あることから，このトンネルが液の交流に重要役をも つことを考觉て和り，䖮牛小管内迷路開口部に特殊な Barriermembrane の存在は認めないと述へ，小管内 は脾洞の如きトンネル様構造を示していると述べ，K1ey 17) (1951) 飞蝸牛小管内口部のワックス充填試験の 結果外リンパの由来に筷して分離膜は決して必要なるの でないと述べている. 及 J. Lempert ${ }^{18)}$ (1952) む Barriermembrane $の$ 存在を否定し，片末 ${ }^{19)}$ (1951) も蟐! 
牛小管は觹液の流入管であり，时には内耳液の流出管で あると考えられると述べ, Barriermembrane は特殊の むのではなく網状織の最外層が附着壁なきためやつ収縮 して組織，及び 細胞が䅕密となつたものであるとし， Barriermembrane の存在を否定している. 大橋 20) (1955) もトリパン青を海狽のクモ償下腔に注入し，組 織伸展法で生体染色し，注入直後に蝸牛两階の差色を認 めて蝸牛小管の流通性を証明 している. 又 Svane-Knudsen 21) (1958) は海犋について組織学的に検索して, 䯟液の一定の流机は蝸牛小管を通つて外リンバ腔へ行 き，又㖪液の一少量は聴神経沿沿つて modiolus に行 くと述べている。

（2）蝸牛小管を介して直接自由な交流を認めない説

Key u. Retzius ${ }^{22)}$ (1870，1875）等は色素を大, 家鬼 のクモ脱下腔に注入する実験を行つて，外リンパ腔と頭 蓋腔との直接の交通は無いであるらと述べ，又人に和い てもクモ膜下腔に注入した色素は，蛕毕小管には達する が鼓室階には到達せず，又蝙牛䉥から注入した色素は蝸 牛小管には達しないことを諗わたと郝告し，Wittmaack 23）（1916）は生きた猫にインデアンインタ，墨汁等の色 素をクモ膜下腔に注入し，短時間に顆粒が螖牛小管に移 行するが，齱室階には到達しなからたことから何等かの 解部学的障害壁の存在を推測し，この小管に柔軟な組織 網のあることを述べている. Karlefores'4) (1923) あ直 接自由な交通が存在するとは軽々には諭ぜられないと述 べ, Meurmann"25) (1929，1930) も家鬼, 人屍でベルy ン青や獣炭リンゲル浮游液をクモ膜下腔に注入しても移 行を認めなかつたこと上り，直接の交通は信ぜられない と述べている. 又 Waltner 26)（1948）江人胎览の蝸牛 小管迷路開口部に特殊の分離膜の存在を発表し “Barriermembrane” と命名し，この膜は半透過性で政液と外 リンパの流動は抬散の現象によるもので流れと称すべき ものとは考えられないと述べ，L. Rüedi 97) (1951)は 協同研究者である K. Graf の実験に和いて海猽の腹腔 内及び皮下にフルオンッセ1ンを注射し，血液，眼房 水，䯣液及び外リンパのその濃度を測定し，蛤牛小管を 通じてのある程度の伝播は認めるが，フルオレッセイン の堌減の程度より見て小管を通じての伝播は主要な役割 を演ずるものではないと述べている. 页木烟 ${ }^{28)}$ (1927) は内耳の生体染色を行つて, 蝸牛小管の網状形成細胞各 カルミンを摄取する事実からこれ等の細胞は清野の言う 網状織内被細胞であろうと推論し，吉尾29)(1951）も石 松子浮遊液を家鬼のクモ膜下腔に注入して一定の流動が
あることから蝸牛小管の通過性を認めるが，そこに境界 䦔の存在を推測している. 加治 ${ }^{30)}$ (1953) は蝸牛小管

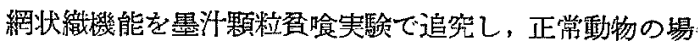
合，鼓室階には殆んど顆粒を認めないが，化膿性蹎㬴桨 では網状織の破摔融解の傾向を認め，鼓室階への進入が 極めて著明である事から，螖牛小管は一つの Barriermembrane であると考学られると述べている．田中 ${ }^{31)}$ (1956) は P32 を用いてこれを䯣腔内に注入し，その結

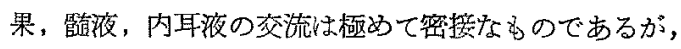
その主要交通路として的央小管を考える時, あ妇程度の 隔壁の存在が考えられると述へている。

圣外リンパの起源については明確に示すところはない 汸，外リンパもしくは内耳液と籍液との性状の比較等上 り両夜が同一物であるかいかてを検討した報告は多く， 羽根 (1918)(前述 ${ }^{7}$ )以外任々れ等が同一物でないこと

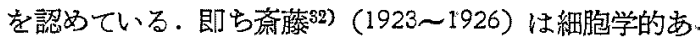
るいは楽洞の内耳移行その他種々の実験を行つて内耳夜 と顝液, 眼房水とは酷似の関係にあるが全く同一ではな いことを認め，高原 ${ }^{33}$ （1933，1934）呐耳液の㠜集反 応について研究して生理的な状態に括いてては蝸牛小管は。 内耳液と顝液との自由で直接な交通路と乙ての意味はな いとの説を変書きする如き結果を得たと報告し，Aldred, Hallpike, Ledoux ${ }^{31)}$ (1940) 等は猫の血液, 骷液, 内, 外リンパの唀圧を測定して, 鹃液と内, 外リンパ 上は同じものとは思和れないとし，Waltner (1950)， はスペクトルを用いて内耳液の蛋白質量を測定し内, 外 リンバは瞋液の 2 倍の蛋白質を含有していることから内 耳液は 䀝液と同一のものとは認められないと述べてい，

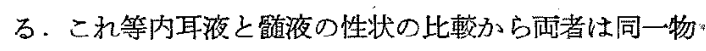
でないとする結諭は，わが後藤教授の下に和ける一連の。 内耳液研究の結果からも明かであり，三宅36) (1953)の 届折率, 中岛 ${ }^{37}$ ) (1954) の水素イネン濃度, 伊藤 38 )

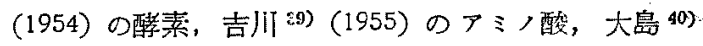
(1956) の沈降反応, 柴田 ${ }^{41)}$ (1956) の䉓気伝導度, 松

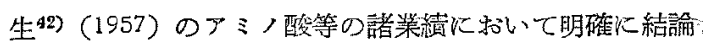
されている。

（3）蝸牛小管以外の経路で䯣腔と連絡ありとする説 Hasse (1881) (前述 ${ }^{3)}$ ) は外りンパの大部分は外y ンバ管を通じてタモ膜下腔と連絡しているが，一部は神 経䩗を通じて交通していると述べ，Rejtö ${ }^{43)}$ (1921) は 外リンバは䯣液とは直接交流せず，間接にりンパ間隐に て改量交流すると述べ, Altmann and Waltner ${ }^{44)}$. （1947）はクモ膜下腔から内耳道底に移動する非常に弱 
い流れのある期を予想し，同氏 45) 46) 等は1950年更に 報告して外りンパの大部分証多りンバ腔自身で生成され るが，一部は德神経鞘間陵，血管周国間嚐 リンパ腔等を 経て髄渡からくることを述べている，又 Svane-Knud-

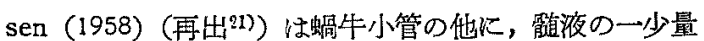
は聴神経に沿つて Modiolus に行くと述べている。

（4）外リンパ腔自身で外リンパの生産を認める説 合馬 ${ }^{47)}$ (1941) は200 例の人屍について実験し, 外り ンバは迷路内で産生されると述べ，蝸牛小管はその排出 管であると言う. Scevola，Gregorini 等 18) (1950) は 薬液の通過実歌を行つて髅液一内耳液の関門の透過は制 限が多いが, 血液一内耳液の関門は高度の透過性がある と結論している. 叉 Kley (1951) (需出 17) は海㩧の 蝸牛小管閉兴後フルオレッセインを血液中に 注射 した 時，眼にこ执が現れると同時に外リンパに現れた。そこ で外りンパは外リンハ腔の豊富な血管係から限外源過で 形成されると推察し，人間では導水管の透過性がはるか に少ないのでこの説は人間の場合極めて重要であると考 えられて捈り，Altmann and Waltner (1950) (再出 -45) 46)）は家鬼，猫，猿に Weed の方法でっモ膜下腔中 江鉄塩を注射し，数分後《動物を殺し，ブルシャンブル 一反応で鉄塩の分布を決定して次の結論を得ている．即 ら外リンパは䯣液から拡散によつて運ばれるかも知れな いが，一方的な流れといつたものはなく外リンパの大部 分は外リンハ腔自身の中でそれも殆んど恐らく血管より 形成されると述へ，その成綘は Kley のそれと甚だよ く似ているのである. 又 Dederding 499（1956）は海㺍 の基整呬転に近い二つの Coil 飞限局してとの “Supra stria”と称する部より外リンパが形成されると発表して いる. 又後藤，三宅，松崎 ${ }^{30)}$ 等（1957）は内耳液の如 き超微量の被検液の性質を検查する一つの方法として， 結晶像を光学顕微鏡的に観察する方法をるつて研究し， 外リンパは䯕液と外リン八腔壁より生成される蛋白質に 富んた血清に近い液との混合液であろうとして，外ッン ハの二起源説を唱えている.

(5) 内リンパに由来するという説

Altmann and Waltner (1950) (再出 45) 46) ) 嫁臣 飞执いて前庭階に達した鉄塩液が前庭階膜を経て蝸牛管 中に㹡散する事実から，外リンパの一部は内リンパから 由来するといらことも考党られると述べている。

II】内リンパの由来に関しては，古くより種タの䒠 験観察にるとつくく説があるが，これを整理すると

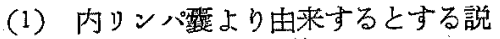

（2）血管条より由来するとする説

（3）前庭階膜を通じて外りンバ上り由来するとする 説

（4）その他の部位より由来するとする説 の4つに大別できるのである.

（1）内リンハ䡬より由来するとする説

Contugno ${ }^{3)}$ (1774) は内リン八湔庭小管を通じて 頭蓋腔に移行していると述べ, Boettcher 51) (1869), Hasse') (1881), Chilow52) (1923) 等は, 内りンパは内 リン八露の上皮細胞から分泌され，内リンパ管を通つて 内耳の他の部分に行つて，そこで略収されると述べてい る. 又 Reudinger 53) (1887) は内リンバは内リン八箦 の上皮間鄚等より脳膜のリンハ腔と交通していると述べ ている. 降つて 1954 年 Seymour ${ }^{54)}$ 虫組織学的研究に

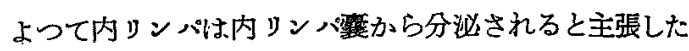
が，同時にこれが唯一の源ではなく血管条や聴栭，㯖斑 の上皮細胞も分泌に与ることも附言している。

（2）血管条より由来するとする説

1851 年 Corti は哺乳動物の血管条を研究し, これが 内リンパの分泌関係ありと述べて上り，血管条淿来 するといら学者は最む多く Schambaugh ${ }^{55)}$ (1909) क これを肯定し，Wittmaack 23)（1916）は内リンパ㤋 泌之洽透の两機能により生成され，分泌には血管条，螺 旋器上皮, 前庭感覚終末細胞上皮等の所謂分泌細胞上皮 が関与し，渗透には膜様迷路全般を被う扇平上皮が関与 していると述べ, Guild ${ }^{66)}$ (1927) は蝸牛管に鉄塩を注 入した実験から，内ッンパは血管条より分必され内リン ハ管を通り内リン八霍に達するし，又卵形覆や半規管を

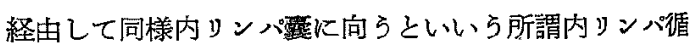
環説を提唱している，河里 57) (1929) は人工的に内耳循 環障碍を起すと血管条の变化が強度で，その際前庭階獏 の沈下と内リンパの濃縮を認め，1934 年富山 ${ }^{58)}$ は血管 条は血管中の異物の濃度が一定度に達する時は常態にお。 いてもこれを血管外に透過せしめ且つ摂取して防㲛器官 としての作用をも有するすのなりと述べている，Miya moto59) (1931), 尾銭 60)（1937）はアトキシール中毒の 動物に批いて血管条上皮層に病变を有したものは前庭階 膜忙沈下し内リンパ腔は狭小刀至は消失することより， 内リンパは血管条より生成されるとした．大沢61)(1956) は血管条上皮細胞内ミトコンドリアの形態, 配列と腎細 尿管上皮細胞のミトコンドリアの類似性より機能の類似 性を推定して㭣り，Saxen ${ }^{62)}$ 6?）（1936，1951）も犬，人 を用いて，組織学的に血管条上皮細胞分分泌する能力を 
有する器官であることを述べているが，内リンパの主た る源は外リンバ経由のるのであることを附言している。 Nachlas and Lurie 64) (1951) は内リンパの 分泌には 血管条の一部が必要であると述べ，前述の Seymour ${ }^{54)}$ （1954）も内リン八高分泌説を唱えているが 同時に 血管 条等よりの分泌子認めているし，Francis and Weille 65) (1955) わ内リンパの分泌調節は血管条の動竫脈弓の 血流調節によつて行われると述へている，又 Smith 66) （1957）は電子顕微鏡下Kミトニンドリアを主として観 察して海猽の血管条や Prominentia spiralisは内リン ‘ீの生産に関与すると述へ，野木67) (1958) も家鬼の血 管条上皮細胞は細胞学的に分汹機能を有するものと考兵 ている. 又 Svane-Knudsen（1958）(再出 21)）は海㺍 に和いて外りンパの一部が 亄室階外側壁の小血管即ち Vas. scala-angurale で吸収され，そこで吸収された液 の一部は再びラセン勒帯の 梁部に出て Stria 上皮の分 泌機能のために貯えられると想像されている。原田 ${ }^{68)}$ （1959）も文内耳リンバ循澴障碍に関する実験を行つて 内リンパ社主として血管条で生成されると述べている.

（3）前庭階跨を通じて外リンパより由来するとする 説

Saxen 62）63（1936，1951）は前述した如く血管带上 皮は分泌能を有することは認めているが，内リンパは主 として，外りンパから搪散によつて生じ間接にはこれは 䯚夜より形成されるものなりと述へ，涉谷69)（1952）は 血管条を有しない耐悽類にトリパン青液を腹腔内に注入 乙，气の際色素は先ず外リンバ組織中の血管内被細胞に 出現し，これから内リンバ腔に透過したと考えられる所 見から，本動物での内リンパ生成源は主として外リンパ に仰ぐものであららとして格り，Naftalin and Harrison 10)（1958）快生化学的研究より外リンパ上り前庭階 膛を通つて内リンハ沉流れがあり，血管条はた心゙撰択的 な場として働くといら仮説を樹ていいる．乙かしこれ等 に対する直接の反論とも考光られる説もある。例えば Lempert, Wever and Lawrence ${ }^{71)}$ (1954) は糜酥し た沜からとり出した脱半規管を材料として実験して膜様 管の壁は内，外リンパ先の他の液体成分の自由透過に 対する barrierをなするのと述べている。

（4）その他の部位上り由来するとする説

Böninghaus5)（1908）は色索を用いて内りンバは内耳 神経外䩗を通じてクモ膜下腔と交通していると述べ，

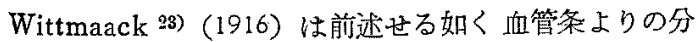
泌を考光ているが，同時にラせン器上皮からの分泌や膜
迷路の屚平上皮からの渗透をも考兵ており，Mygind 792

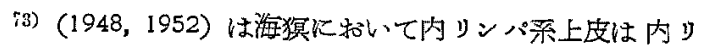
ンパを能動的に分泌すると述べ大沢74) (1958) は海獏の 組織学的所見よりラセン勒帯上皮細胞の分泌機能をる推 定して沶り，Nachlas and Lurie (1951) (前揭 $\left.{ }^{61}\right)$ ) 血管条の他にも源があることを推定し，Smith (1957) (前揭 ${ }^{66)}$ ) 血管帯の他 Prominentiaspiralis K内リン 八生産を認め，原田 (1959)（前揭 68)）主管帯の他化 平衡器慔様部からの分泌を考学ている。

しかし乍ら实験的に陰性の成䅡を得た報告も多く， Fleischmann 9)（1918）はトリパン青を皮下，静脈，腹 腔内に注射したが内耳に恮く現れずと言い，Siebenmann ${ }^{75)}$ (1919) は，内リンパは内リン八露を通じて脳 咸のリンパ腔と交通するといら Reudinger（前述 ${ }^{53)}$ ) の説に反対している. 高森 ${ }^{26)}$ (1920) 性色素を海猽の蝸 牛款内に注入し血管条に色素摄取を認めず，木畑 ${ }^{28)}$ （1927）はりテホンカルミンを家愚の静脈に注入し，内

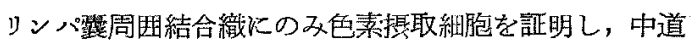
77) (1922) はカルミンを家香の静脈に反覆注入したが内 耳に色素を掑取した細胞を認めず，木畑8（1927）は色 素のクモ膜下腔注入に括いて向管案細胞には色素摄取を

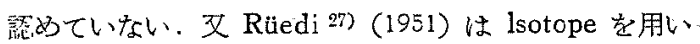

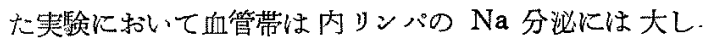
て役彗を有しないと述べている。

以上の如く諸種の実験成積が挙げられておうこれ等の 実颐は要䄪すれば

1）色素，薬物等による追跡実験方法

2) 内耳液の交䢙路の胎生学的, 組潡学的研究法

3）内，外ッンパ間の物理化学的寒験研究法

4）血液循還の問題

等より推論されている上考えてよからう。しかし近年 放射性同位元素が色素比代つて追跡实験に用いられるよ 5になり，Rũedi 27)（1951）は内，外りンぷの起源に関

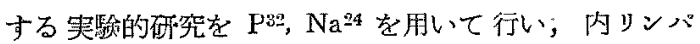
中の $\mathrm{Na}$ は外リンパのそれと全く異つた態度を示し， ほんのその一部分の值を示したに過ぎず，血管条には多 数の血管が存在するにも拘らず，限外㴓過は内リンパ中 への $\mathrm{Na}$ 分泌では大した役割を演じないように思われ。 ると述へ, 叉 Bordeaux 大学の Portmann ${ }^{78)}$ (1954) 等もJod ${ }^{131}, \mathrm{P}^{32}$ を用いて猫の内耳液の生理に関する契 鍳を行い理諭的には外リンパに対しては直接倹查法。内 リンパに対しては Historadiographie がよいとし，今 後迷路生理学的淕当な Isotope の研究が必要であり， 
この意跦で 40 日の半減期を有する $\mathrm{Na}$ が理論的に成 功 を保証するるのであるらとしている。

\section{第 3 章 実験材料並びに実験方法}

第 1 節 実戨 材料

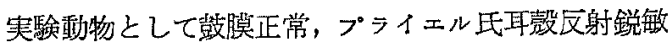
なる体重 $2 \mathrm{~kg}$ 前後の家鬼及び $250 \mathrm{~g}$ 前後の海猽を用い た. 被検液の採取洗は上記動物に後述方る如き各檑の方 法でもつて $\mathrm{P}^{32}$ 若しくは $\mathrm{Na}^{24}$ 安注入して直後むしく 岋ある時間後に一举に断頚し，直らに耳翼後部切開で耳 一骨胞を露出し，次いで骨胞を゙破り蝸牛空を明視する，源

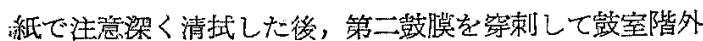
リンバを採取し，次いで䨩科用根管リーマを用いて基整 廻䎐の前庭階へ小孔を開け，前庭階外りンパを採取し， 次いで第二鼓脱を除去して基喽迴転部の基底挘を明視す る.こ〉に掠いて再び濾紙を朋いて充分に外リンパを拭 い去り，倍率 10 倍，焦点距離 $4.5 \mathrm{~cm}$ のルーペを使用 して蝸牛管内リンパを採取するのであるが。そのために 愔当教室内耳液矿究グループの考接作製による支持台付 ミタロマニプラトール条伐用し，尖端を尖鋭にしたる瑠 璃色硬賀ガラス慜毛細管を基底膜を穿孔したところで放 置して，毛細管現象で上昇する内リンパを採取した。 そ の際赤血球の有無を検することは勿論，穿刺過度に上る

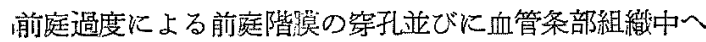
の刺入を特比注意して避けた。な括毛細管は被検液採取 海に蒸溜水，アルコール，エーテルにて各々 3 回洗桜乾 燥して用いた，血液は耳翼部林悄血管より採取し，その 量も文各被検液採取の際之同一液柱によつた，各被梌液 採取の順序は敱室階外 シンパ，前庭階外リンパ，蝸牛管 内リンパの順序である。

第 2 節 実戨方法

内耳内，外リンパの isotope による tracer 実駼は Graf ${ }^{20)}$ 等の直接法を行つた。な推注射用追跡子として $\mathrm{P}^{32}$ 及び $\mathrm{Na}^{24}$ を用いたが，P流液 $1 \mathrm{cc}$ にフェ，

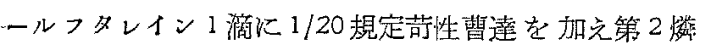
酸曹達の形で中性にした後，リンゲル氏液でこれを稀勫

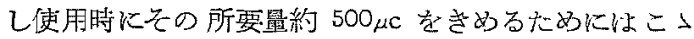
《表示した放射能減数表に則って減数計算した。. 又 $\mathrm{Na}^{24}$ は蒸溜水でその都度適当量炕稀釉して用いた。

測定方法並びに測定䒾置としては前記の如く採取した

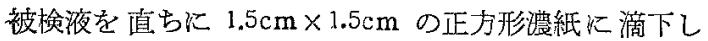
Dish K入れ，ガイタ一氏管（神戸工業株式会社製放射 能測定装置 SC-100 近法部数器）及び Scintillation •Counter を用い，同一材料に就いて 10 分間 3 回測定し

\section{A 表 P32 の放射能減数表（半減期 14.3 日）}

\begin{tabular}{|c|c|c|c|c|c|c|c|}
\hline 3 歌 & 觇的能 & 日数 & 政制能 & \begin{tabular}{|l|l|l|}
$\theta$ & \\
\end{tabular} & 政的能 & 日数 & 放制故 \\
\hline 0 & 10000 & 14 & 5073 & 40 & 14.39 & 66 & 408 \\
\hline 1 & 9527 & 16 & 4604 & 42 & 1306 & 68 & 370 \\
\hline 2 & 9076 & 18 & $4 / 79$ & 44 & $1 / 85$ & 70 & 336 \\
\hline 3 & 8617 & 20 & 3793 & 46 & 1076 & 72 & 305 \\
\hline 4 & 8238 & 22 & 3443 & .18 & 976 & 74 & 277 \\
\hline 5 & 7840 & 24 & 3125 & 50 & 886 & 76 & 251 \\
\hline 6 & 7476 & 26 & 2836 & 52 & 804 & 78 & 228 \\
\hline 7 & $7 / 23$ & 28 & 2574 & 54 & 730 & 80 & 207 \\
\hline 8 & 6786 & 30 & 2336 & 56 & 662 & 82 & 188 \\
\hline 9 & 6.965 & 32 & 2120 & \begin{tabular}{|l|}
58 \\
\end{tabular} & 608 & 84 & 171 \\
\hline 10 & $6 / 59$ & 31 & 1924 & 60 & 545 & 86 & 195 \\
\hline 11 & 5867 & 36 & 1717 & 6? & 495 & 88 & 140 \\
\hline $1 / 2$ & 5590 & 38 & 1585 & 64 & 450 & 90 & 127 \\
\hline 13 & 5325 & & & & & & \\
\hline
\end{tabular}

た。

第3 節 各唡実㓰群の具体的方法

(1) $\mathrm{P}^{32}$ 並に $\mathrm{Na}^{24}$ 心葴内注射実跧

P32 及び $\mathrm{Na}^{24}$ 溶液を直接心蔵内に注射し直後もしく は短時間（1～30 分）内に断頭し被検液を採取して湘定 に供した。

（2） $\mathrm{P}^{32}$ 椎骨動脈内注射実験

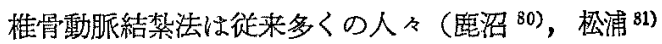
等)に上り色々案出されているが，私は椎骨動脈を露出 すると同時に注射針を拽入するため，露出操作が讯速で 且つ出血を最小限にとめる目的をるつて神岡氏 ${ }^{82}$ の実 験方法に従つて注入を行つた。

(3) P 92 クモ膜下槽注入実跧

クモ膜下槽注入は後頭下穿刺によつた. 即らウレタン 麻酥 30 分にして家臣を固定䧾中に腹位に固定し，外後 頭下結節を目標にしてその下約 1 横指の部を $\mathrm{P}^{32} 500 \mu \mathrm{c}$ を容れた $1 / 3$ 針装置のッデルクリン注射器をるつて穿刺 し，後頭載域膜を経て小脳延喵槽化達せしめ，一旦吸引 して液の流出を磪め，充分注射夜と混和せしめた後，極 めて徐々に注入した。注入に際しては副損賃を殿ける上 うに努めたばかりでなく，誤って脳幹の副損傷を起した ような症状を呈したもの及び出血を呈したもの等は全て 例数より除外した．クモ脱下腔注入例としては，(1) 単 なるクも膡下膑注入例と，(2) 注入後数回パンビングを して加圧した例との 2 璉頪の锤物についての実騟を行つ た。

（4） $\mathrm{P}^{32}$ 皮下及び静脈内注射実験

海犋の皮下及び静脈内に $500 \mu \mathrm{c}$ を注入し，30分，60 分後に断頭测定した。 
（5）螖牛小管閉蛪実験

家鬼を用い稲葉(9)（1952）の実験方法に則り，脳腔を 開き一側の蝸牛小管外口部を明視した後該部を烧灼後止

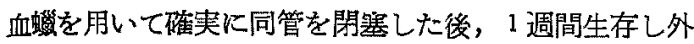
見上何等異常なきを確かかた上，P32 の心臟内注射，も しくはクモ膜膜下櫣注入を行つたものに就いて測定し た.

（6）オートラジオグラフイー

放射能の"写真作用を利用して内，外リンパ币への放射 性燐の移行を間接的にも証明するために，海猽の心藏内 飞 P $\mathrm{P}^{32} 500_{\mu \mathrm{c}}$ を直接注入後 5 分して断頍し鼓室階外り ンパ，前庭階外リンパ，螖牛管内リンパ及び血液を採取

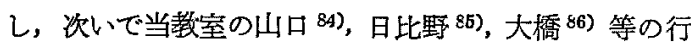
つた方法に做つて血管条，基底板，卵形擎を採取し，各 液及び水分を濾紙に掝つた諸組織を顕觊鏡用被覆ガラス 代載せ充分乾燥せしめたる㷋，この面を感光度 18 度， 富士 X 線フィルム上に直接密着せしめ，冷暗室に 2 週 間放置感光せしめたる後，“さくら”SDX-33 現象液を 用いて $18^{\circ} \mathrm{C}$ 的 4 分現象後，富士 Fix 定着液にて定着， 水洗 20 分後乾燥せしぬ，感光写真標本を得た，な特こ の Contact method KX 線フイルムを用いたのは， その乳斉の解像力は劣るが， $\beta$ 線感光度が最良であつて Survey autoradiography には最適と考占られ，放射 性燐の存在量は黒化濃度によつて容易に決定することが できるからである。

（7） $\mathrm{Na}^{24}$ 前庭階及び鼓室階注入実験

海猉を用い,ウレダ麻醉後，生体のま〉直接第 2 鼓 膜より僦室階外リンパ中に，又前庭空より前庭階外リン パ中に，硬質毛細管ピペットをもつて Na ${ }^{24}(0.2 \sim 0.5 \mu \mathrm{c})$ を注入し，10 分〜 60 分後に断頭し被検液を採取して測 定した。

\section{第4 章 実験 成 績}

第 1 節 $P^{32}$ による追䟢実験

(1) Pas 心䁍内注射例

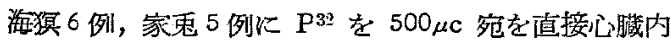
飞注入し短時間内に断顽して得た実駼成續は表 (1) 及び 表（2）の如くである.

即ち心蔵内に $\mathrm{P}^{32}$ を直接注入した正常海狽に和いて

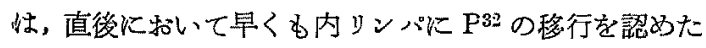
が，外リンパには必ずしも出現せず，出現しても内リン パ和けるものに比して明かに小であつたが，短時間後 （1分，3分）には全例共内，外リンパ中にその出現を認 め，之の量も直後のむのに比しいずれも大となつてお
（表 1） P32，心藏内注射例（正常疑猠6 例)

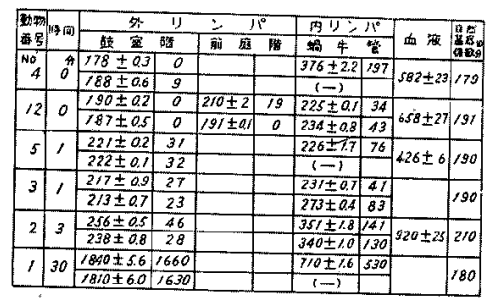

諳：(1)成䋊の数字は荚测した Count 数であ る。但し内，外リンパの右項には自然 基底係数を差引いた数を示した。

(2) 同一番号動物について上下㯕は夫々左 右耳の测定成緻を示す

(3)（一)とあるは Contamination を認 めたろめ破藮した例である。

（表 2) $\mathrm{P}^{32}$ 心臟内注射例（正常家鬼 5 例）

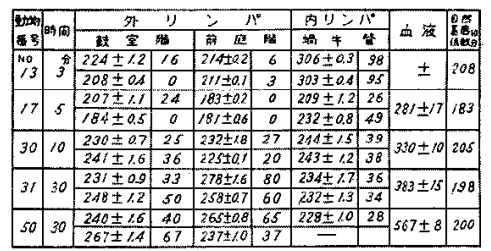

陆：(1)成繦の数字は実測した Couut 数であ る。但し内，外リンバの右項には自然 基底係数を差引いた数を示した。

(2) 同一番号動物飞っいて上下欄は夫々左 右耳の測定成績を示す

(3) (一) とあるは Contamination を認 めたろめ破菒した例である。

り，30分後に执いてはその量が更に著明に增加して拈 り，この恃間では外リンパ中の量は内リンパより多量之 なっている。

一方同様操作を施した正常家鬼においては短時間後 (3分，5分）において内リンパには全例 $\mathrm{P}^{32}$ の出現を認 めたが，外りンパに扎いて瑺に必ずしも出現を見ず，

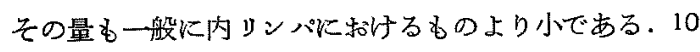
分，30分後に括いては内リンパ，外リンパ共に常にそ の存在を認めるが血液中の量と比較するとき内リンパ中 の量は短時間後のものに比してむしろ娍少の碩向にあり 他方外リンパ中の量恃铻時間後のるのに比して增加の傾 向にあり内，外リンパ中の量を比較するとむしろ外リン パの方に多量となつている。

(2) $\mathrm{P}^{32}$ 椎骨動脈内注射例

家患 2 例に $\mathrm{P} 32 ， 500 \mu \mathrm{c}$ を椎骨動脈内に注射して得た 
（表 3） $\mathrm{P}^{32}$ 椎骨動脈内決射例 (正常家乘 2 例)

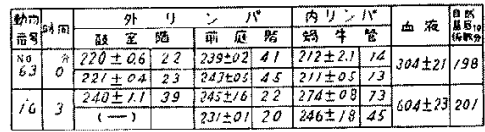

詰：(1)成績の数字は实測した Count 数であ る。但し内，外りぇパの右项には自然 基底低数を差引いた数を示した。

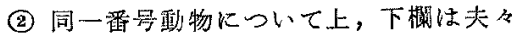

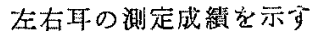

(3) (一) とあるは Contamination を認 めたはめ破雍した例である。

成綪は表（3）の如くである。

即ら直後並に短時間後（3分）に抏いては内，外リン パ共に $\mathrm{P}^{32}$ の出現を認めその量は前庭階外リンバにや」 多いかと考支られるが，大略心葴内注射家虫の成續と似 たものである.

(3) P39 クモ脱下槽注入例

(i) 無操作例に就いて

家㭸6例に，クモ膜下槽に $\mathrm{P} 92,500 \mu \mathrm{c}$ を極めて徐々 注入して3 分〜60分後に断頭して得た成績は表（4）の 如くである。

即ら 3 分 60 分後の全例に和いて内リンパへの $\mathbf{P}^{32}$ の移行を㑇めなかつた. 外リンパに打いては3分後には 認められたかつたが，5以後に和いては漸く鼓室㮏に移

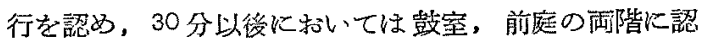
めるを得，その量は其に時䦭の経過につれて增大し鼓 室, 前庭の両階を比較する時常に敖室階の方に多量に存

（表 4） $\mathrm{P}^{32}$ 多モ膜下槛注入例 (i) 䑾操作例 (正常家鬼 6 例)

\begin{tabular}{|c|c|c|c|c|c|c|c|c|c|}
\hline \multirow{2}{*}{\multicolumn{2}{|c|}{ 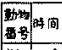 }} & \multicolumn{2}{|c|}{ 外 1} & \multicolumn{2}{|c|}{$10^{\circ}$} & \multicolumn{2}{|c|}{ 为リンバ } & \multirow{2}{*}{ 血 } & \multirow{2}{*}{ 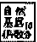 } \\
\hline & & 3 & 暏 & $\sqrt{17}$ & 飠 & 4 平 & 管 & & \\
\hline & & $2 / 8 \pm 0.3$ & 0 & $217 \pm 06$ & 0 & $220 \pm 0.1$ & $o$ & & \\
\hline & & $220 \pm 0.1$ & 0 & $220 \pm 0.5$ & 0 & $219 \pm 23$ & $\theta$ & & \\
\hline & & $243 \pm 0.6$ & 26 & $2 / 4 \pm 02$ & 0 & $2 / 7 \pm 0.3$ & $o$ & & \\
\hline 26 & & $247 \pm 0.8$ & 30 & $2 / 7 \pm 0 t$ & $a$ & $215 \pm 0.5$ & 0 & & 21 \\
\hline & & $244 \pm 04$ & 30 & $2 / 5 \pm 2 A$ & 0 & $2 / 4 \pm 0.6$ & 0 & & \\
\hline 31 & 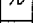 & $249 \pm 0.7$ & 3.5 & $2 / 3 \pm 13$ & $a$ & $2 / 2 \pm 03$ & 0 & $248 \pm 02$ & 21/4 \\
\hline 29 & 30 & $133 \pm 0.2$ & 3.3 & $2 / 3 \pm 10$ & 13 & $198 \pm 0.5$ & 0 & $246+17$ & 200 \\
\hline & & $241 \pm 0.6$ & $A 1$ & $208 \pm 2.6$ & 8 & $796 \pm 0.3$ & 0 & & \\
\hline 28 & 60 & $247 \pm 15$ & 50 & $238 \pm 0.7$ & 41 & $198 \pm 1 / 1$ & 0 & $2 \pm 3$ & 197 \\
\hline & & $262 \pm 0.9$ & 65 & $247 \pm 17$ & 50 & $197+60$ & $\frac{a}{2}$ & & \\
\hline 49 & 60 & $\frac{271 \pm 2.2}{284 \pm 15}$ & $\frac{68}{81}$ & $\frac{233 \pm 20}{257+0.3}$ & $\frac{30}{54}$ & \begin{tabular}{|l|l|}
$203 \pm 0.5$ \\
$201 \pm 2.3$
\end{tabular} & 10 & 200 & \\
\hline
\end{tabular}

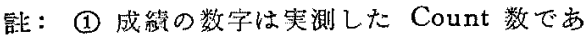
る.但し内，外リンパの右項には自然 基底係数を差引いた数を示した。

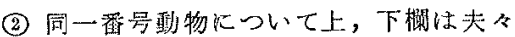
左在固の测定成鹤示示

(3) (一) とあるは Contamination を認 めたうめ破琵した例である。
在する事を知つたな打 5 分以内に血液中にその移行を 認めるか゚，その量は247士0.3の程度であつた。

(ii) 加王例に就いて

家鬼 3 例に就いてクモ膜下槽に $\mathrm{P}^{32}, 500 \mu \mathrm{c}$ を極めて 徐々に注入して数回のパンピングを行つて加压し1分及 び 5 分後に断頭して得た成續は装 (5) の如くである．但 し表の時間（分）はパンピング終了時より測つたもので あるが，パンビングに要した時間は約 10〜15 秒であつ たので算入していない.

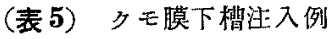

〔ii〕加圧例（正常家鬼 3 例）

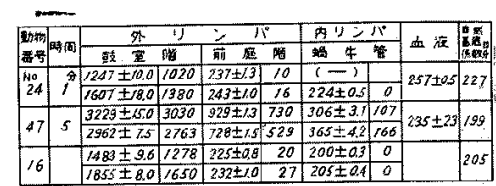

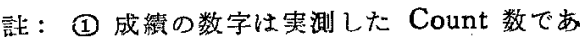
る。但し内，外リンパの右項には自然 基底係数を差引いた数を示した。

(2) 同一番号動物について上，下闑は夫ネ 左右耳の湘定成績索示引。

(3)（一)とあるは Contamination を諗 めたらめ破洷した例である。

即ら注入1分後の動物に扎いて既に外リンバには教室 階, 前庭階其いずれも極めて多量の $\mathrm{P}^{32}$ を認めたが，内 リンパリには3例中1例（No. 47）に和いてのみこれを を認めたに過ぎず，しかもその量は外リンバに叔るる のに比して少量である. 又外りンバの致室, 前庭の酞階 を比較すると全例烡豉室階の方が遥かに多量であること を認めた。な打 No. 47 動物例の P 32 出現量は他の2 例 に比して極端に多量であつた．又血液中への移行は，無 操作例より速かで 5 分以内に認められるがその量に関し ては無操作例のそれと余り变りは認められながた。

（4） P 32 发下及び静脈内注射例

海猽 4 例に就いて皮下（2例）及び静脈内（2例）に $\mathrm{P} 32 ， 500 \mu \mathrm{c}$ を注入し 30 分及び 60 分後に断頭して得た 成絗は表（6）及び表（7）の如くである。

即方皮下注射例においては，30分後の例に执いては 内リンパ $\mathrm{P}^{32}$ の出現を見ず，外リンパに和いては豉 室，前庭両階共同程度の量を認めたが，60分後におい

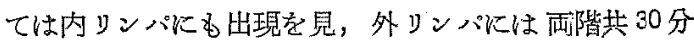
後のむのに比しわずかに多く認めることができた。

一方静脈注射例に䏡いては 30 分及び 60 分後の両例共 内，外リンパのいず扎もその存在を認め，その量は内 
（表 6) $\mathrm{P}^{32}$ 皮下注射例（正常海猽 2 例）

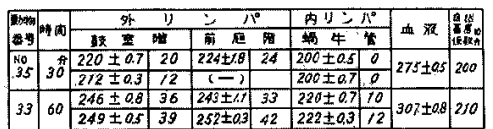

棓：(1)成縟の数字は实測した Count 数であ る，但し内，外リンパの右項には自然 基底係数を差引いた数を示した。

(2) 同一番号動物にっいて上，下㯗は夫夕 左右耳の測定成績を示子

(3)（一）とあるは Contamination を認 めたらめ破䐑した例である。

（表 7) $\mathrm{P}^{32}$ 静 派内注射例 （正学海爆 2 例）

\begin{tabular}{|c|c|c|c|c|c|c|c|c|}
\hline \multirow{2}{*}{\multicolumn{2}{|c|}{ 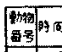 }} & \multicolumn{2}{|c|}{ 外 11} & \multicolumn{2}{|c|}{ バ } & 内りンハ & \multirow{2}{*}{\multicolumn{2}{|c|}{ 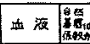 }} \\
\hline & & 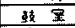 & 筧 & 青底 & 楂 & 部 & & \\
\hline \begin{tabular}{|l|} 
mo \\
\end{tabular} & & $223 \pm 0.7$ & 25 & $216 \pm 0.3$ & 18 & $208+04 \quad 10$ & 8 & \\
\hline 34 & 30 & $236 \pm 0.9$ & 38 & $2 / 8 \pm 26$ & 20 & $216 \pm 101 / 8$ & & \\
\hline 36 & 60 & $253 \pm 0.4$ & 46 & $215 \pm 09$ & 38 & \begin{tabular}{l|l}
$229 \pm a 2$ & 22 \\
$230+1$ &
\end{tabular} & & \\
\hline & & $249 \pm 0.2$ & & $242 \pm 0,3$ & & $234+2,21<1$ & & \\
\hline
\end{tabular}

註：(1)成續の数字は実測した Count 数であ る。但し，内，外リンパの右項には自 然基底倸数を差引いた数を示した。

(2) 同一番号動物について上,下欄は夫々 左古耳の测定成䠝を示す

(3)（一）とあるは Contamination を認 めたろめ破雍した例である。

リンパ，前庭階，鼓室階の順に多いが大きな差異はな W.

しかして皮下注射例と静脈注射例とを比較すると一般 に静脈注射例に拈ける万が僅が皮下注射例に比して 内，外リンパヘの出現量が多いことが窥われるのであ Ђ.

（5）蝸牛小管塞後実験例

螖牛小管閉塞実験に 成功せる家鬼 5 例に就いて $\mathrm{P}^{32}$, $500 \mu \mathrm{c}$ の心藏内注射（2 例）及びタモ膜下啃内注入例 (3

（表 8）䖮牛小管闒鎖後 P32 心葴内注射例 (家秉 2 例)

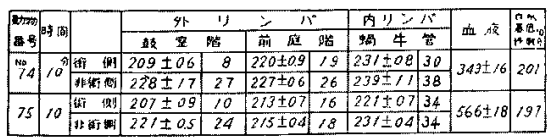

註：(1)成續の数字は実測した Count 数であ る. 但し，内，外リンパの右項には自 然基底係数を差引いた数を示した。

(2) 同一番号動物について上，下橍は夫ふ

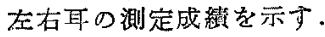

(3) (一) とあるは Contamination を認 めたらめ破鿊した例である。
（表 9) 蛤牛小管閏塞後 P32 クモ膜下槽注入例 (家雷 3 例)

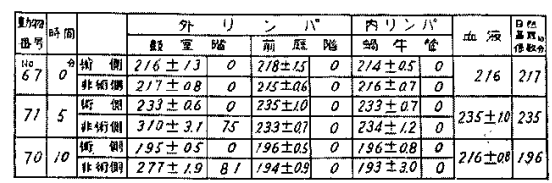

弪：(1)成續の数字は実測した Count 数であ る。但し，内，外リンパの右項には自 然基底係数を差引いた数を示した。

(2) 同一番号動物について上，下欗は夫々 左右耳の測定成績を示す.

(3) (一) とあるは Contamination を認 わたらめ破集した例である。

例）を行い，直後むしくは 5 分〜10 分後に断頭して测 定して得た成䅡は夫々表（8）及び表（9）の如くである.

即ち螖牛小管開塞後の心臓内注射例に搔いては，注射 後 10 分に括いて非手術側には内，外》ンパ共に P32 の 移行を認かいずれの側に和いても $\mathrm{P}^{32}$ の量は外リンパよ り内リンパにや〉多からたが鼓室，前庭岡階に和ける差 異は殆んどなかつた。一方手術側の鼓室側の鼓室階外り ンパには $\mathrm{P}^{32}$ は極めて少量であり，内リンパ，前庭階外 リンパに和ける量は非手術側のそれに比しや小小ない碩 向を認め，又内りンパの方が外リンバに护るよりや〉 多量であつた。

蝸牛小管閉塞後のクモ膜下槽内注入例に扎いては注入 直後の例では術側，非手術側共内，外ッン パ及び血液の いずれにも P 32 の移行を認めず注入後 5 分及び 10 分の 例については術側に沶いては直後の例之同じく内，外》 ンパ及び血液のいずれにも $\mathrm{P}^{32}$ の移行を認めず，非術側 にお゙いてはすべて㜞室階外リンパにのみその移行を認め ることができた。な㨁液中には 10 分後に少量出現す るのを针めた。

第2節 P32 によるオートラジオグラフイー

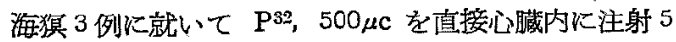
分後に血液，血管条，内，外ソンパ，ラセン器及び卵形

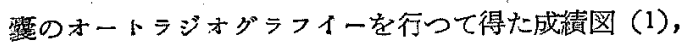
（2），(3）に示可如く，全例共血液，血管条（図1），内 リンパ（図2）には，相当量の黒代濃度を認めた点より， $\mathrm{P}^{32}$ の藷名な存在を確認することができたが，前庭階外

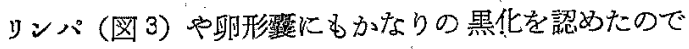
ある。これ等に匡してラセン器の組織の黑化は極めて軽 度であるに過ぎなかつた。 
オートラジオグラフイー

図（1）血管 带

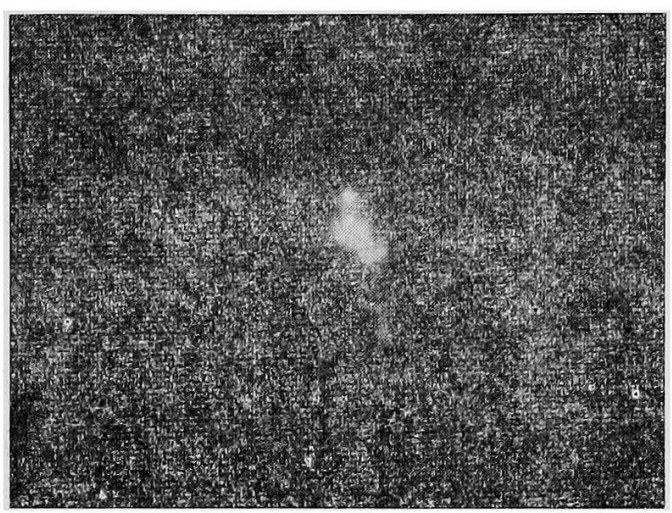

図(2) 内リンパ

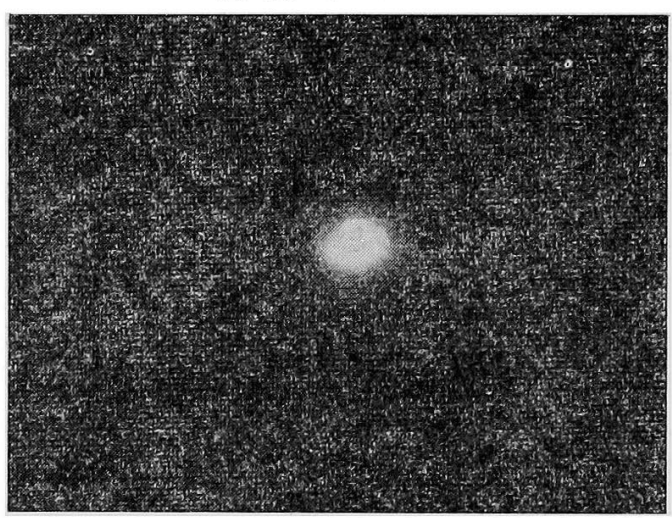

図(3) 外りンパ

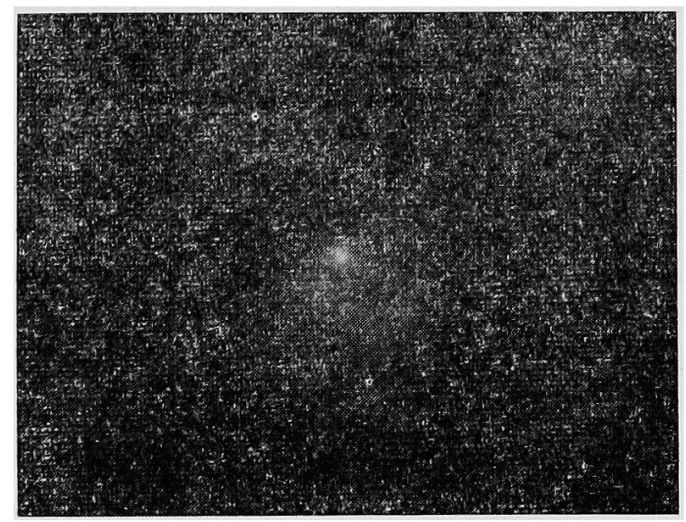

第 3 節 $\mathrm{Na}^{24}$ による追跡実験

(1) $\mathrm{Na}^{24}$ 心歲内注射例

海犋 3 例の心蔵内に直接 $\mathrm{Na}^{24}, 500 \mu \mathrm{c}$ を注射し 5 分, 10 分，30 分後に断頭して測定し得た成績は表 (10)の如 くである.

（表 10） $\mathrm{Na}^{24}$ 心欌内注射例（海猽 3 例）

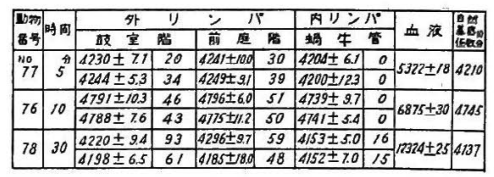

註：(1) 成績の数字は実測した Count 数であ る. 但し, 内, 外リンパの右項には自 然基底係数を差引いた数を示した。

(2) 同一番号動物について上,下欄は夫々 左右耳の測定成續を示寸.

(3)（ー）とあるは Contamination を認 めたうめ破䢂した例である.

即ち注射後 5 分のものにおいては未だ内リンパにその 出現を見ず $\mathrm{P}^{32}$ の場合と大いにその括ももきを異にし， 外リンパに括いては鼓室階，前庭階共にほが同程度の存 在を認め，これ等の所見は注射後 10 分のものに批いて も同様でありたら゙わずかに外りンパ中の量の增加を認め るのである．乙かして注射後 30 分のものに秃いて始め て内リンパ中に $\mathrm{Na}^{24}$ の移行を認め，外リンパ中の $\mathrm{Na}^{24}$ の量は注射後 10 分の例に比し政室階に增量を認めるが， 前庭階中のそれには大した変動を認めなかつた。 又内り ンパ中の量と外リンパ中の量を比較する時内リンパの方 が遙かに少量であつた.

（2） $\mathrm{Na}^{24}$ 䣫室階及び前庭階注入例

海獏 3 例に就いて生体のま入直接第二鼓膜より鼓室階 外リンパ腔中に, 更に前庭空膜より前庭階外リンパ腔中 に $\mathrm{Na}^{24}$ 0.2 0.5 $\mu \mathrm{c}$ を注入して得た成績は表 (11) 及び 表（12）の如くである.

即ら表（11）の $\mathrm{Na}^{24}$ 鼓室階内に注入例に拈いては 10 分及び 30 分後は勿論 60 分後に执いても内リンパ中には $\mathrm{Na}^{24}$ が認められないが，前庭階外リンハ腔内には注入 後 10 分に秃いても多量にその出現を認めたのである. 又最初に注入せる嫴室階中の量は時間の経過と共に順次 減少することを知つたが，他方前庭階中の量は10分〜 60 分の間にもその変動は軽度である. 乙かし乍ら鼓室 階中の $\mathrm{Na}^{24}$ と前庭階中の $\mathrm{Na}^{24}$ との関係を見ると, 10 分〜30 分に抋いては 前者の量が 後者の量より大である が，60分後においては逆に前庭階に㸱ける量が 踥室階 
（表 11） $\mathrm{Na}^{24}$ 競室階腔内直接注入例 (海璂 3 例)

$\left(\begin{array}{ccc}\text { 注入単倍 } & \text { 約 } 0.2 \sim 0.5 \mu \mathrm{c} \\ \text { " } & \text { 量 } & \text { 䄪 } 0.001 \sim 0.002 \mathrm{cc}\end{array}\right)$

\begin{tabular}{|c|c|c|c|c|c|c|c|c|c|c|}
\hline & & 外 & J & ע & & & 93 & & & \\
\hline 逶号 & & 鼓 室 & & 前 庭 & 售 階 & & 号牛 & & & \\
\hline 82 & $\begin{array}{r}\text { 分 } \\
10\end{array}$ & $\begin{array}{c}6120 \\
\pm 6.6\end{array}$ & 970 & $\begin{array}{c}5676 \\
\quad \pm 9.0\end{array}$ & 526 & & & & & \\
\hline 83 & 30 & $\begin{array}{c}5420 \\
\pm 11.7\end{array}$ & 620 & $\begin{array}{c}5120 \\
\quad \pm 5.1\end{array}$ & 320 & & .0 & & & \\
\hline 80 & 60 & $\begin{array}{c}4973 \\
\pm 18.0 \\
\end{array}$ & 540 & $\begin{array}{l}5382 \\
\pm 10.0 \\
\end{array}$ & & & $\begin{array}{l}00 \\
59.6 \\
\end{array}$ & & & \\
\hline
\end{tabular}

辟：(1)成縝の数字は実測した Count 数であ る。但し，内，外リンパの右項には自 然基底保数を差引いた数を示した。

(2) 同一番号動物について上，下㯕は夫々 左右耳の测定成績を示寸

(2)（一）とあるは Contamination を認

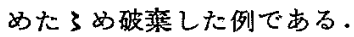

(表 12) $\mathrm{Na}^{24}$ 前庭階腔内直接注入例 (海猽 3 例)

$\left(\begin{array}{ccc}\text { 注入単位 約 } & 0.2 \sim 0.5 \mu \mathrm{c} \\ \text { " 量 } & \text { 䄪 } 0.001 \sim 0.002 \mathrm{cc}\end{array}\right)$

\begin{tabular}{|c|c|c|c|c|c|c|c|c|}
\hline 转物 & & & D & 之 & & 内リン & & 自然 \\
\hline 番号 & & 鼓 室 & & 前庭 & 階 & 蝸 牛 & & 10 分 \\
\hline $\begin{array}{l}\text { No. } \\
84\end{array}$ & $\begin{array}{l}5 \\
10\end{array}$ & $\begin{array}{c}4530 \\
\quad \pm 7.0\end{array}$ & 21 & $\begin{array}{r}4881 \\
\pm 9.0\end{array}$ & 430 & $\begin{array}{l}4449 \\
\pm 11.3\end{array}$ & 0 & 4451 \\
\hline 81 & 30 & $\begin{array}{c}5039 \\
\pm 17.3\end{array}$ & 0 & $\left|\begin{array}{c}5250 \\
\pm 15.0\end{array}\right|$ & 200 & $\begin{array}{l}5045 \\
\pm 10.0\end{array}$ & 15 & 5050 \\
\hline 85 & 60 & $\begin{array}{c}4661 \\
\pm 9.7\end{array}$ & 0 & \begin{tabular}{|c|}
49822 \\
\pm 16.0
\end{tabular} & 310 & $\left|\begin{array}{c}4668 \\
\pm 8.5\end{array}\right|$ & 0 & 4672 \\
\hline
\end{tabular}

䏻：(1)成絰の数字性実測した Count 数であ る. 但し, 内, 外上ンパの右項には自 然基底係数を差引いた数を示した。

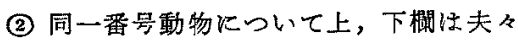
左右耳の測定成績を示す

(3) (一)とあるは Contamination を認 めたろめ破菜した例である。

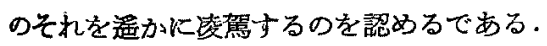

圣表 (12) の $\mathrm{Na}^{24}$ 前庭階腔内に注入例飞未いては， 内》ン パは 30 分後の 1 例 (No. 81) 飞拈いて痕跡的 Кその出現を認めたのみであり，'椇室階への出現も10 分後の 1 例 (No. 84) のみに少量認められるに過ぎなか つた. 又前庭階外リンパ中の $\mathrm{Na}^{24}$ は時間的には㱠んど その消長が認められなからた。

\section{第5 章 䋓括並に考按}

私の行つた実虽成績を総括し考按するに，

（1） P 32 の心臓内注射を行つた場合，海犋並に家乘 においていずれるほざ相似た成續を示し，注射後短時間 にP32を内リンパ中には全例，外リンパ中には少数例飞 これを認め，内リンパ及び外リンパ中の $\mathrm{P}^{32}$ 量の関保は 初期には内リンバに多く，時間の縙過と共に外リンパの 万がむしろ增量するのであり，内リンバ中の $\mathrm{P}^{32}$ 量の消 長は，これを血液中の $\mathrm{P}^{32}$ 量と対比する時，時間の経過 と共に減少して行く傾向を認めるのである。

又家雨の 椎骨動脈内に: P ${ }^{32}$ 注射を行つた場合の成結 は，心臓内注射の場合之ほ心゙同様傾向を示すが，“前庭階 外リンパに現れる量がや」多い。

以上の実験成續より先ず考光られることは，少くとも

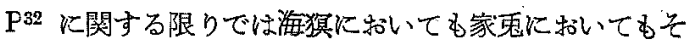
の注射直後より蝸牛管内リンパに $\mathrm{P}^{32}$ の存在を認めたこ とより，内リンパは血行性飞螖牛管壁上り速か儿分泌さ れる之考学るのが妥当であり，Böttcher ${ }^{5 ! 1}$ (1886), Hasse 3) (1881), Chilow ${ }^{22)}$ (1923), Reudinger ${ }^{53)}$ (1887) 等之言らが如く内リンパは内リン八雚上り生成される之

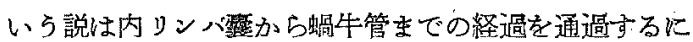
要する時間的な問題を考党る時は首肯する事はできな い.

さて螖牛管壁より速かに排出されるということは硡 認できたか゚，乙がらば内リンパが螖牛管壁のいがなる 個所上り生成されるかを考党るに，第2章でのべた如

々Corti 以来 Schambaugh ${ }^{50)}$ (1909), Wittmaack 23) (1916), Guild 56) (1927), 河野 57) (1929), 営本 ${ }^{59)}$ (1931)，尾鐵 60) (1937)，大沢 61) (1956), Saxen 62) 63) (1931，1951)，Smith 66) (1957)，野木 67) (1958) 及び

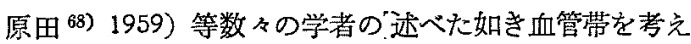
るのが最も妥当であるが，これが能動的分泌によるもの か滤過によるむのかといら点については私の実験成禎か らだけでは確信することはできない，

な技私の実験成續に叔いて，注射直後に外リンバにも $\mathrm{P}^{32}$ を認めた例があることから，外りンパは内リンパか ら前庭階裳を通じて由来するというが如き Altmann and Waltner 45) 46)（1950）の説炕は首肯し難く，内, 外リンパには別途の起源を考党るものであり，㕛時間の 経過と共に外 リンパ中の $\mathrm{P}^{32}$ は次第に增量し遂には内り ンバ中の量を凌鴐することより，血液より外リンパ中 のP $\mathrm{P}^{32}$ の移行は内リンパの場合より徐々ではあるがをし ろ持続的の性質を有することが考えられるのである。 
次に家雭の椎骨動脈内 $\mathrm{P}^{32}$ 注射例の成續は心蔵内注射 の場合とほぶ同椂な傾向を示すことは；たとえ心葴内注

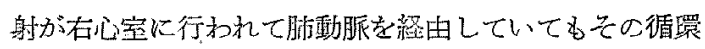
上の慧義には殆えど差異のないことを示している. 又一 侧の椎骨動脈に注射して雨側の内耳へ殆んど平等に出現 したことは，脳底動脈の経路を考える時は当然の事柄で 西当。

（2）家鬼のクモ膜下橧 $\mathrm{P}^{32}$ 注入实際に扔、ては，単 なる注入例（無操作例）では，先ず鼓室階外リンパに P32 が現われ，次いで前庭階外りンバ中現われるが， 内リンパ中には出現を認めず，艾外りンパ中のP吾は封 間の経過之共に增量するが，大きな值ではなく，又鼓茎 階中の量は常に前庭階中の量より大である.

一方パンピングを行った例（加圧例）では早期上り外 リンパの雨階に極めて多量の $\mathrm{P}^{23}$ の出現を認めるのであ り, 雨階を比較する時鼓室階中に遥かに多い，又内リン パ中に $\mathrm{P}^{32}$ の出限を相当量に認めた 1 例があるが，この 例に和いては他の例に比して外リンパ中の量る極端に多 く，加圧の程度が大なるため蝸牛小管網状織並に膜迷路 壁の機械的損傷の程度が大であつたょめ特殊の成綪を示 したのではないかと考壳る。

今内耳液と䯣液との交流について考光る時，直接ク モ膜下橧に諸種の色素液を注入してその内耳への移行 を観察する実験が主体となつて考察され，Contugno 3) (1774) が外リンパは蝸牛小管を通じて頭蓋腔に䔟行し ていると発表して以来, 多数の学者によつて剈腔内色素 注入による内耳への移行が証明されている。しかし乍ら 内耳夜々髄液の交流を認めた学者においても，直接自由

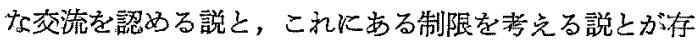
在する事は既に第 2 章炕拈いて詳しく述べた通りであ ๖.

これを私の実騒成綪より考觉る時, 単なるクモ膜下槽 注入例 (無操作例) では 5 分を経過した後に最初认鼓室 階外リンパ中にこれを認め後には前庭階中に現われる が，常に必ずその量は鼓室階外リンパの方が多い点上

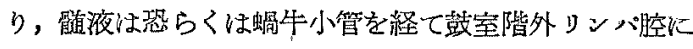
現われるといら事が将えられるのであるが，注入後了分 ではこれが現われず，文冬の量も比較的少量に過ぎず時 間の経過沉つて極めて徐々飞増量する点よりして両液 の交流は認めるが，これは直接自由な交流ではなくある 制限が考えられ，もしくは物理的な掋散現象をもつてし ても充分説明し得られる程度のものである。

このことは雪にパンピングを行つた実験（加圧例）で
一㬝明らかである。即ち加圧した場合外リンパ腔特に吉 室階には速かにP年 の出現を見，との量す無操作例に上 して柾好て多い，か」る事け既火片末 ${ }^{19}$ （1951）の। リパン青による笑験でる諰められている所で西り。こま らのことより蝸牛小管を介しての两液の交流は，特殊。 人工的施圧操作といら条件下に沶いて初的て無制限自目 となることが侾光られるのである。

しかし乍らこのことから直らに正常時には Waltne: :6) (1948) の言らが如き“Barrier membrane”之私 ナる組織学的な隔壁が存在すると断定することはできな

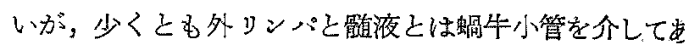
る程度の交流があるということができる。しかしこれは 生理的に噵液が無制限に蝸牛小管を通過主る事を示すも のではなく，㕛外リンバが髄液のみにこの起源を有する ものという証明にもならない。

なおある制限された流動は，“Barriermembrane” と称吨られる如きある種の隔壁が存在するためか，ある いは攵物理的な抁散現象で説明される程度の流動を考克 るべきか住にわか炕は断定し得ない。

な括特殊の例外をのぞいては内りンパには $\mathrm{P}^{32}$ の移行 を認めなからた点より，前庭卦䐜を経由して外リンパ より内りンバが生成されるという Saxen 62) 63) (1936. 1951）等の説には容易には首肯できず，少くとる㮖極的 にこの膜空通じて一方的な流れがあり一側液は他側液仡 由来するというが如きことは否定できるのである。

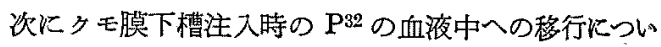
て見ると，私の実験では，鼓室階外リンパ中に現われる よりや」遅れて血液中に出現し，その量も比較的少量で あるが，パンピングを行つた場合に标いては無操作例よ りや」早期に出現するが，その量には汪之えど差を認め ない.

即ち無操作例と加圧列との間に $\mathrm{P}^{32}$ の血液中移行量に 余り差異のない点から，タモ膜下槽注入時の血液中への 吸収は簿朕腔よりなされたものと考党る。何故ならば若 し外リンパ腔壁よりの吸収が主役を演ずるものと仮定す るならば，加壬例に乱いては無操作例に比して外りンハ 中の $\mathrm{P}^{32}$ 量は極めて大であるから血中への吸彼にも大い に差異があつてしかるべきであるからである。

（3）海猽に $P^{32}$ 友下注射した場合汇和いては。先 ず外リンパ中に出現し，これに遅れて内リンパ中に出現 し，いずれの場合にもその量性少ないなな外りンハ嵱 両階に打ける $\mathrm{P}^{32}$ 量には㱠えで差異はなく，時間の経過 によつてむ急速な增量は垫められない。 
一方静脈内に注射した場合においては，皮下注射の場 合に比して早期より，内，外リンパ中に出現を見，ての 量む皮下注射の場合に比して一般に多いが，必缄内注射 海猉の場合よりは少ない，な赫敖脈注射時の出現量は内 リンパ，前庭階外リンパ，鼓室階外リンパの順に大とな るが，その差は比較的僅かである。

以上のこと入先に行つた心臓内注射及び椎骨動脈内注 射の成績とを併せ考允ると，各種注射時の血行性の内耳 液への $\mathrm{P}^{32}$ の移行は, 必蔵内注射, 椎骨動服内注射, 静 脈内注射，皮下注射の順に小之なり，特に内りシパの 移行は皮下注射時において極めて小である。

か」る点より薬風を内耳液中に達せしめて何等かの治 療効果を得んとする場合，薬剤の内耳液への移行度は前 記の順ではあるが，実地臨床上の問題として考觉ると， 静脈内注射が操作が比較的簡単なるにも拘らず内，外两 リンパヘの移行は心葴内及び動脈注射に比してそれ程务 らない点より，最も適当なるのと考える。

なおっモ膜下槽に注入したりあるいはこれにバンと゚ ンダを施した場合の $\mathrm{P}^{\mathbf{2} 2}$ の移行は外りンふ腔にとぶまる わのであるから，内リンパへの薬剤移行といら点を主腿 として考光た場合は静眽注射に透く及ぶものではない。

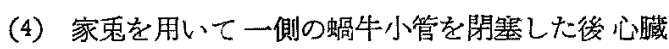
内に $\mathrm{P}^{32}$ を注射した場合，非手術側の成績は正常家鬼心 践内注射実鈳例の成績（表2）と后ડ゙同様であるのは当 然であるが，手術側においては内，外リンの共にP32の 出現は少量であり，特に鼓窒階外ロンバへの出現は微量 である。

しかして，この鼓室階への出現の微量であることにつ いては次の二つの説明が考党られる。即ち，この実験例 では蹎液由来のものについては一応触れないことにて $\tau$,

（1）外シンパが前庭, 鼓室の両階旺から生成される と仮定すると，螖牛小管を閉算するよらな操作を行なつ た場合，特に鼓室階壁よりの生成が阻害されて，その結 果政室階に P 今2 の出現が徽量になつたと，考えるか，あ るいは丈、

（2）外シンバが前庭階壁から生成されるとして，蝸 牛小管開瑟時に，両階の流通障害が惹起されて，その結 果鼓室階に $\mathrm{P} 32$ の出現が徽量になった，とも考えられる のである.

そこで P02 心欌内注射实験（表1及び2），及び椎骨 動脈内注射実験（表3）の成續を参照すると，P江関 する限りではその注入後鼓琶階外リンバ先ず出現する
例と前庭階外リンパ先ず出現ずる例があり，従つて螎

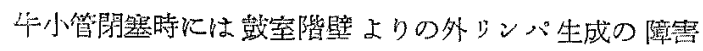
（上記（1）の説明）を考学る方が妥当である.

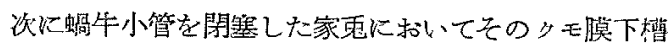
にP32 紊注入した場合を見るに，非手術側の成綪は正常

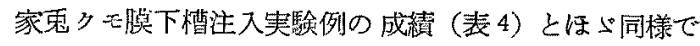
あるが，鼓室階中への出現はや小多量であり，血夜中へ の出現は轻微である。一方手術側においてて肉，外リン パV P² の移行を認めない

か〉る点より少くとも $\mathrm{P}^{32}$ の移行炍関する限り，Hasse (1881) の考えるが如き神経鞘経由とか, Rejto ${ }^{43}$ ) (1922) の言う如きりンハ間陵経由とか，Altmann and Waltner ${ }^{44)}$ (1947) の言うが如き聴神経鞘間隙とか血管 周囲間隐りンハ腔経由とか, Svane-Knudsen 21) (1958) の言らが如き㹔神経に沿つた結路とかは考えられず，䯣 腔と外リンハ腔との交通路としては蜩牛小管が考克られ るのみである。

（5） P ² を心臟内に 注射した海埧のオートラヂオグ ワフイーの結果恤管条及び蛤牛管内リンバの黑化濃度 は相当大であり外りンパや卵形整がこれに次ぎラセン器 の黒化謴度は小である。

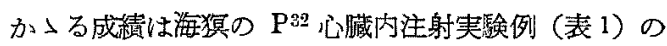
成績を再筤認せしむるものであり，これ等の点より内リ ンパの生成は血管条による上ころ大なる事は明らかであ

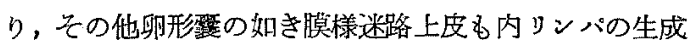
に何等かの関係を有することが推察される。文外リンバ

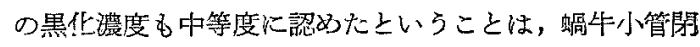

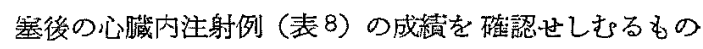
であって，外りンパ恃外リン八腔壁よりも生成され得る ことが更に明かとなつた訳である。

従つてこれ等各種実駼の成績を綜合すれば外リンパの 由来は，一部は蝸牛小管を経て顝液より移行し，一部は 外ワンバ腔自身より生成され得ることが更に明かとなつ た訳である。

従つてこれ等各種実験の成辕を綜合すれれは外りンバの 由来は，一部は螖牛小管を縚て䯚液上り移行し，一部は 外リンパ腔自身より生成されたもの之考克られ，既に後 藤, 三宅，松陭 (1957) 等によつてその結晶像の就究の 結果から言方れている如く外リンバ生成の二起源説に一 致するのであり，発生学的にもこの説の妥当性が肯け る.

なお゙シセン器のオートラヂオグラフイーにも軽度の黒 化を認めたが，これは標本作彆中に完全には内耳液を除 
去する雅ができなからたつめか，あるいは組織中にある 程度の $\mathrm{P}^{32}$ の移行があつたつめか惊断定できない。

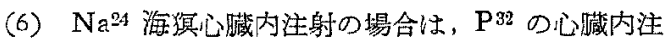
射实験例（表1）に比して内リンパ中への出現が遅く微 量である。一方外りンパ中への出現の時期には变化はな く時間の経過と共汇鼓室階外リンパでは增量するが前庭 階外リンパではその增量は㮌く㪕度であり，しかもこれ 等の量は F 32 の場合に比して小でする。か力る成綘は

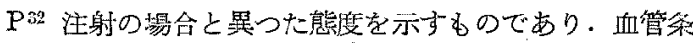
を内ジバの主たる分泌部位と考える場合各種けオンを 均等份分必するものとは考克難く，そこには何等かの撰 択性が存するものと思考される。

なおこのことに関しては Graf and Poretti :9) (1950) は $\mathrm{P}^{32}$ と $\mathrm{Ne}^{24}$ を用いて海猉の皮下注射艺行つて $\mathrm{Na}^{24}$

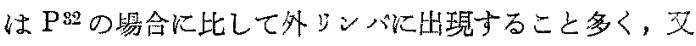
$\mathrm{Na}^{24}$ の出現を同一動物の内，外リンパについて比較す る時外りンパに多く、内シンパに少ないことを明かにし て扣り，血管条には多数の血管が存在するにる拘らず， 限外濾過は内リンバ中への $\mathrm{Na}^{24}$ 分必という点では大し た役割を演じないがら，この部の上皮細胞は選択的防绵 的 Barrier を形成している上らに思加机ると述べて和 ク，私の成績もこの点に関しては良く一致するところで ある。

（7） $\mathrm{Na}^{24}$ の政室階注入海猽に打いては，比較的早期 に既に前庭階外リンバに相当多量の $\mathrm{Na}^{24}$ を認め，しか 6時間の㳗過と共に酦室階外シンパ中の $\mathrm{Na}^{24}$ は著明に 減少し, 前庭階中のそれは变動が少ない点より, 鼓室階 上り前庭階に向けての外リンパの流動, もしくは款室階 外リン八腔への䯣液の一眭的流入，あるいは灭鼓室外; ンハ腔壁上りの四收といらことも考光られる。

更に又内リンパには遂に $\mathrm{Na}^{24}$ の出現を見なからた点 より Saxen 62) 63) (1936, 1951), Naftalin and Harri son 20)（1958）等の言らが如く迷路臊を透過しての外り ンパより内ッンパへの1ォン移動は $\mathrm{Na}^{24}$ 㳊関する限り では考えられないのである。即ちイオン物質が細胞脱を 透過する事は認めても，前庭償の如き迷路䐜が単なる細 胞膜の如きるのであるとするならば，外りンノ゙腔中に注 入した $\mathrm{Na}^{24}$ は容易に内リンバ中に出現すべき笘である

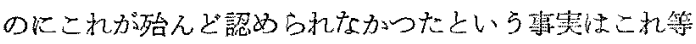
迷路膜の機能を単なる細胞膜に比ずべきものとは考えら れない, 従つて Naftalin and Harrison (0) (1958) の 如き人々の考方方あるいは，迷路膜は策のような充分な 透過性があるとい5 Meyer ${ }^{87)}$ (1951) の仮説火は否定
的とならさるを得ず，むしろ Lempert 71) (1954) の寻 らが如人膜様管の壁は内，外リンパやその他の夜の自由 透過に対する Barrier をなすとの考光方に同調するる のである.

Хこの点に関しては私の実験操作からしても試獣を断 頭してより被検試料の採取終了までのある時間的経過に 标いても $\mathrm{P}^{32} も し く は \mathrm{Na}^{24}$ があるいは内リンパにのみ あるいは外シンパにのみ認められた例があるといらこと からも，動物の死亡によつて迷路䐜の透過性が変化して 無制限な透過を許すという事は考えられないのである。

更に又 $\mathrm{Na}^{24}$ の前庭階注入海猽においては，同階腔内 の $\mathrm{Na}^{24}$ には消長が少なく，比較的早期の1例に批いて 豉室階外リンハ腔中に移行あるのを認めた他俚その移動 が少ない点上り，前庭階中に叔る $\mathrm{Na}^{24}$ の拡散は小で

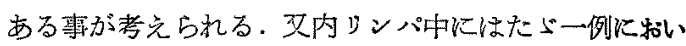
て㾪跡的な存在を認めたのみであるのでこれが实験上の 愦りにもとづくものか前庭階漠を通じての内リンパとの 微量の交通を認むべきかはにわがは断定できない。

以上の如く Radio-active isotope 便用した事仗よ つて，攽来の色素突験に比して上り生理的，上り合目的 な且つ短時間内の迫跡実験が可能であり数々の知見を得 だが，特に本研究の主眼である内，外リンバの生成関 する知見を整理綜合すると，

（1）内リンパの生成に関しては，P32 心葴内注射実 鈳（表 1 及び表 2) 及び椎骨動脈内注射实駼（表3）に 搃いて注射直後上り蜩牛管内シンパに $\mathrm{P}^{32}$ の存在を認め たことより，内リンパは血行性に蝸牛管壁より速が分 泌されることを知り，先の個所としては組織学的に研究 した文献に徵して血管策が最も妥当と一応考劣たが，こ のことは $\mathrm{P}^{32}$ 心臓内注射動物の Autoradiography（図 1) で血管条に黒化濃度が最も大であることから明かな

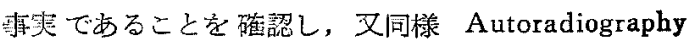
の結果から卵形慗の如き膘迷路上皮も内リンパの生成に 何等かの関係を有することを推察し得心。しかし作ら

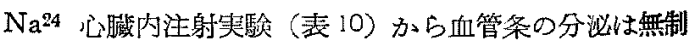
限でなく何等かの物貿撰択性があることを知つた。

なお，内リンパが内リンパ雚上り生成されるといら説 には，心臟内注射実験（表 1，2）の結果加らこれを否定 し，内リンバが前庭階荧を経由して外リンパより由来す るという説沉は，クモ璄下槽 P 32 注入実験（表 4)及び $\mathrm{Na}^{24}$ 政室階注入実験（表11）の結果よりこれを肯定す る雨はできなからた。 
（2）外リンパの生成に関しては，先つ心臟内注射実

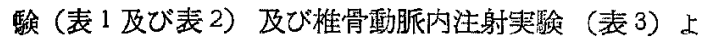

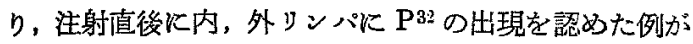
あることから，先づ内，外リンパの生成には別途の起源 を考え，又時間の経過と共に外リンパ中への $\mathrm{P}^{32}$ の出开 峙次第兽して内リンパ中の量を淩駕することから P 32 汇関しては外リンパの生成は内ッンパの場合より徐々で 恃あるがむしろ挎続的な性質を有することを知つた。

更にクモ脱下槽 $\mathrm{P}^{32}$ 注入実験で単なる注入例（表 4) では，注入後5分で始めて俱室階外リンパに P32 め，その後前庭階外リンバにも現われるがその量い政室 階外リンパの方が多いことから，䯣液は恐らくは螖牛小 管を経て鼓室階に現われると考えたが，3分絈のものに 屾現われずその量す比較的少量に過ぎず，時間の経過に つれて極めて徐々に增量する点から外リンパと晸抜との 交流は認めるにしてる直接自由な交流てはなく，Waltmer 26) の言う “Barrier-membrane” の加き制限膜莫 考えるか，あるいは又物理的拡散現象でも充分説明でき る程度の交流であると考えた。

しかしてP32を注入してパンビングをした例（表5）

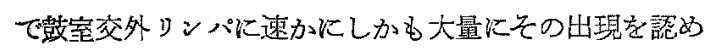
た点から人工的加圧操作といらょらな特殊の条件下で， 始外リンパと噵液の交流は無制限自由となることが わかり，これ等の事から生理的な状態に和いては外りン パと逃液とは蝸牛小管を介してある程度の交流があるこ とが明かとなつた。

なお蝸牛 小管閉篹後心荗内注射実験（表8）の結果矢 張り外りンパとる $\mathrm{P}^{32}$ の出現を認めたことから外リンパ 《は蝸牛小管を経由して髄液上り由来するもの〉他，外 リンハ腔壁より生成されるもの」あることを知り，この ことはオートラジオク゚ラフィーからも碳認することがで き，以上のことから外リンパの二起源説に頨同した。

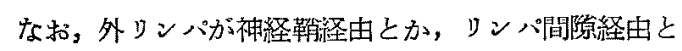

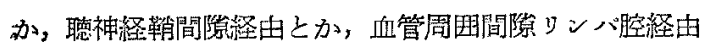
とか，聴神経沿つた経路を通つて髄腔よりもたらされ るといら説には，蝸牛小管閉兴家息のクモ脱下槽 P32 注 入実験（裁9）の結果からこれて否定する静ができたし， 又外リンパは内リンパから前庭階獏を通じて由来すると

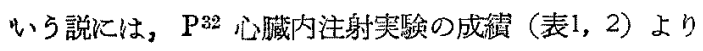
否定した.

\section{第 6 章 結 論}

放射性同位元素 $\mathrm{P}^{32}, \mathrm{Na}^{24}$ を追跡子として用いて，正 常海猉及び家秋の内耳液の生成生理について倹萦して次
の如き結果を得た。

(1) P32 心藏内注射を行つた場合，海冝並に家鬼に おいていずれもほぶ相似た成縝を得た。即ら注射後速か に内リンパ相当量の $\mathrm{P}^{32}$ の存在を認め, 外リンパをあ 少量乍ら早期よりその存在を認め，これは時間の経過と 洪に增量して内リンパ中の量より大となる。なお家象に 批いては内リンパ中の量は血中量に比して時間之共に減 少する傾间にある。

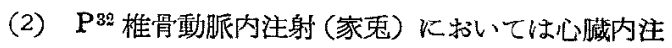
射の場合之大略同様の傾向を示寸が前庭階外りンパに現 われる量がや小多い。

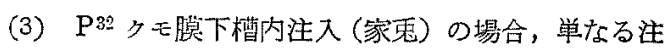
入例（無操作例）では先す豉室階外リンパ，次いで前庭 階多リンバ中に琴われるが，内リンパKは出琴を認め ず，又外りンバ中の量は時間の経過と共に增量するが大 きな值ではなく，页鼓室階中の量は常に前庭階中の量よ り大である.一方バンビングを行つた例（加压例）では 早期より外リンハ特に蚑室階に極めて多堦の出現を見る が，内リンバへの出現は殆んど認められない

（4） P 82 皮下注射 (海璂) の場合先ず外リンパ中に出 現し，これに遅れて内ッンパ中に出現するが，いずれの 場合もとの量は少ない。

（5） $P^{32}$ 静脈内注射 (海猽) の場合には皮下注射の場 合より早期飞内，外リンパ出現し，艺の量む皮下注射 の場合上り多い。

（6）螖牛小管閉塞後 P32 心淢内注射（家禹）を行っ た場合，手術側の内，外リンパへの出現は少量であり。 特に鼓室階外リンパへの出現は微量である.

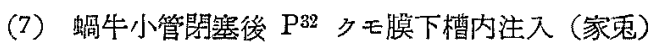
を行つた埸合，手術側飞おいては内，外リンパ共 $\mathrm{P}^{32} の$ 移行を認みない。

(8) P32 心藏内注射による内取のオートラジオグラ フィー (海猽) の結果, 血管条及び螖牛管内リンバの黒

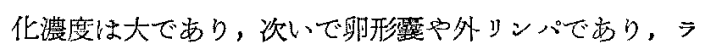
セン器の黒化震度け聂も分る。

（9） $\mathrm{Na}^{24}$ 心缄内注射 (海犋) の場合は，P3! の場合 に比して内リンパ中への出琴が遟く、且つ微量であり， 外リンパ吃のの出現の時期汇変化はないが，その出見量 は小である。

(10) $\mathrm{Na}^{24}$ 致室階注入（海璂）の場合，比较的早期 に前庭階外リンパに相当量の秒行を認め，乙か子時間の 经過と共に鼓室階中の $\mathrm{Na}^{24}$ は藷明に減少し前庭階中の それは変動が少ない。 
(11) $\mathrm{Na}^{24}$ 前解階注入 (海埧) の埸合，同階中の $\mathrm{Na}^{24}$ には消長が少ない.

(12) Radio-actve-isotope を使用当ることよつて 従来の色葲奏鈳等に比して上り生理的，含目的な追跡奏 験が可能である。

以上の英験成霣より次の如さ事が云い得る。

即ら内リンパの生成には，P劣用いた場合には主と して血管条よりの能動的な急速な産生加考えられる他，

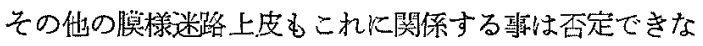
いしかし乍ら $\mathrm{Na}^{24}$ を朋いた場合には $\mathrm{P}^{32}$ といさつか その態变を異にし，血管条の撰択性の機能を䓅をざるを 得なからた。

又外リンハの生成は内リンバの生成之は別途の起源を

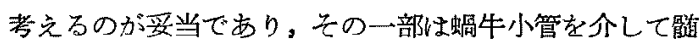
液との交流による事が考えられるが，正常時に和いては 無制限自由な交流とは考占られず，又外りンパの一部は 外リン八膑壁上り比較的徐々に生成されることが明かと なり，外リンバの二起源説に賛するものである。

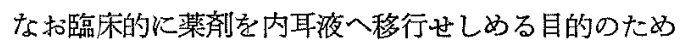
には静脈内注射が適当であることを゙然つた他，迷路䐉の 機能を単なる細胞朕に比すべきものではないということ を知つたのである。

以上の如く私は諸承の实験の結果から従来異説の多い 内，外リンパの生成について，少くとも $\mathrm{P}$ とaに関 する限りに和いては一らの芫解を得たものと考兑る。

$$
\text { 文献 }
$$

1) 後藤修二：音感受障䅞をめぐる問題，日耳藇，55 巻, 257 頁, 昭 27 (1952). 2) Du Verney (1683), Valsa'va (1707), Pacchioni (1721)：（31）引用. Contugno (1774), Hirtl (1860), Hasse (1881): (31) 引用. 4) Webel-Liel: Experimentelle Nachweiss einer kommu nication d. Endo.u perilabyrinthischen Räumen des Menschlichen intracrania. le Räumen. Virchow's Arch. f. pathol. Anat " physiol. Bd 77, 1879. 5) Boeninghaus (1908) (31) 引用. 6) Fleischman: Studien über der Herkunft des labyrinthwasser. Arch. f. Ohr. usw.:

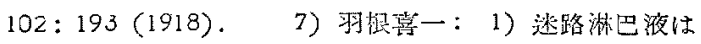

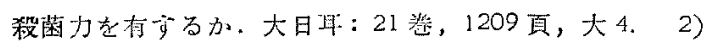

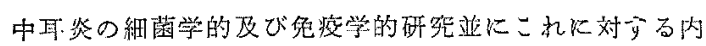

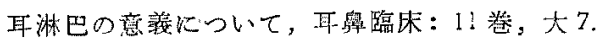
大烟展夫: Experimentelle Studies on the relation between the Cerebrospinal and labyrinthine fluid.

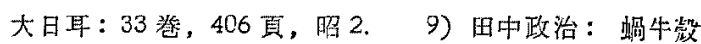
端水管の官能化就て，大日耳： 36 巻，431 面，639面， 颔 5 (1930). 10) Karbowski: Vergleichend anatomische Studien itber den Aquaeductus cochleaeund über seine Bejiehungen zum Subarachnoideal. raum des Gehirns. Monatschr. f. Ohrenhk. usw.: 64: 687 (1930). 11) Jampolsky: Über morphologischen Zusammenhang des Subarachnoiealraumes mit dem labyrinth. Mschr. Ohrenhk. usw.:

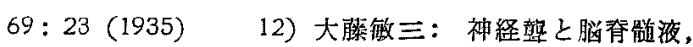
日耳嶝, 261 頁, 昭 $23(1948), 13)$ 大藤澉 三：人体に持け可蛹牛踤導水管の Barrier Membrane (裍膜)に就て，日耳鼻：54 然，204頁，昭 26 (1951)。

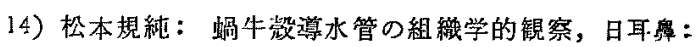
53 巻，4号 (総会号)，12 頁，昭 25 (1950). 15) 松 本規純：蝸牛敌導水管の組蟣学的研究（II）, 特に淋巴 交流機䔝飞就て，日耳鬼：54 巻，97頁，昭 26 (1951)， 16)松本規純：蛊牛教導水管の組織学的研究，日耳-鼻: 55 巻, 401 面, 昭 27 (1952). 17) Kley: Zur Herkunft der Perilymph. Zschr. f. Laryng.: 30: 486 (1951). 18) Lempert, Meltzer, Wever, Lawrence: $\&$ Rambo: Structure and Funktion of the Cochlear Aquaeduct. Arch. Otolaryn: 55: 134 (1952).

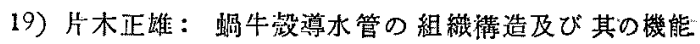
に関子る寒蹒的研究，日耳奥：54巻，97真，昭 26 . (1951). 20）大橋和：内耳血管带に関ある実験的研 究，第 2 編 血管带の機能に関子る実験的研究, 名古屋 医学: 第 69 巻, 149 面, 炤 30 (1955). 21) SvaneKnudsen: Resorption of the cerebro-spinal fluid in guinea pig. An experimental study. Acta Otolaryng. . 49: (1958). 22) Key u Retzius: Studien in der Anatomie des Nervensystems und des. Bindegewebes, (1875). 23) Wittmaack: Über die path-anat. und path-phys-Grundlagen dernichteittige Erkrankungsprocesse des inneren Ohres. und des Hörnervous. Arch. f. Ohr-usw. Heilk: $99: 21(1916)$ 24) Kalefores: Zeit. f. Anatomie and Ertwicklungsgeschichte: 67: 113 (1923), (17) 引用. 25) Meurmann: 1) Zur Anatomie und physiologie des Aquaeductus cochleae. Z. Laryng. usw: $17: 401$ (1929). 2) Zur Anatomie des Aqureductus cochleae nebsteinigen Bemerkungen iiber dessen physiologie. Acta Soc. Medic. fenn. 
Duodecim (FId) 13: l (1930). 26) Waltner: Barrier Membrane of the Cochlear Aqueaduct: Histologic Structure on Patency of Cochlear Aquaeduct. Arch. Otolaryng: 47: 656 (1948).

Riüedi: Some Animals Experimental Findings on the Function of the Inner Ear. Ann. of Otol.: 60, 993 (1951). 28) 木烟压夫：Die Vitale Farbstoff Ausspeicherungs des labyrinths. 大日耳: 33 巻, 597

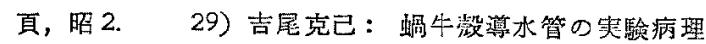
学的研究, 日耳鼠: 54 巻, 97 面, 昭 26.30) 加治俊 。信：内耳液の变動機耺に関する实羷的研究，日耳鼻： 56 巻, 701 頁, 昭 28.31 ) 田中裕一：蝸牛小管開通 飞関する並び勳物実験的研究，日耳劲：59 巻，1899 頁, 昭 31.32 ) 齐藤霉（後松本と改名）：内耳淋巴 液の研究, 耳鼻臨床, 15 巻, 大 11,16 巻, 215 頁, 233 面, 大 12,17 巻, 172 面, 大 13,19 巻, 185 面, 195 頁, 大 15.33$)$ 高原高三：干鼻科颃域に特圢る血球凝集 反応火関方石研究，大日耳鼻：39巻，541 頁，昭8.耳 臨床；28 巻， 453 頁，昭9. 34) Aldred, Hallpike Ledoux: Observation on the Osmotic pressure of Endolymph. J. physiol., 99: 446 (1940).

Waltner, Raymond: On the chemical composition of the hüman perilymph \& Endolymph. Laryngoscope 60：912 (1950). 36) 三宅弘：内耳性難埴 《関する研究, 特に䯣液と内耳液の用折率について, 日 耳番： 56 巻，907 面，昭 28 (1953). 37) 中島稳: 聴覚障碍に括ける䯙液及び内耳液水萃イオン濃度に関主 当研究，日耳奥：57巻，779面，昭 29.38 ) 伊藤利

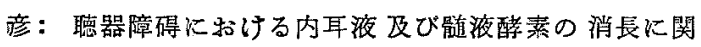

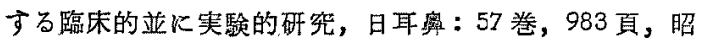
29. 39）吉川久夫：聴覚障碍に和ける跹液及び内耳 液厂ミノ酸に関する研究，日耳奥：58巻，696頁，昭 30. 40) 大島司馬夫：内耳液, 䯣液の沈降反応関 する研究, 日耳奥：59巻，131 頁，昭3!，41）柴田象 太郎：聴器厗碍に打ける内耳液及び骫液の電気伝導度 炕関する研究，日耳奥：59巻，176頁，昭 $31.42 ）$ 松 生栄治: 内耳内, 外リンバ液のアミ, 酸比関す五研究, 旧耳鼻：60巻，502頁 昭 32 . 43) Rejtö; Über des Flüssigkeitssystem des labyrinth. Mschr. Oh. renhk., 55: 324 (1921). 44) Altmann and Walt. ner: The Circulation of the labyrinthine Fluids. Ann. of Otol., $56: 684$ (1947). 45) Altmann and Waltner: Newinvestigations on the physiology of the labyrinthine Fluids. Laryngoscope, 60: 912 (1950).

46) Altmann and Waltner: Further investigations on the physiology of the labyrinthine Fluids. Ann. of Otol.: 59:656 (1950). 47) 合馬文彦：内耳淋巴の流動，大日耳：47炇，542 頁， 昭 16 (1941). 48) Scevola. Ventra-Gregorini, Leo. nardelli et Cantu: Surle passage des medicaments der sang aux liquides labyrinthiques. pract. Oto. Rhino-Laryng: 12: 38 (1950). 49) Dederding: Guttulate formation in the outcr angle of the scala vestibuli. Acta otolaryng: 46:526 (1956). 50) 後藤修二，三宅弘，松崎久：内耳液に関する研究，第 2 報，(外yン八蛊牛小管。领液の関倸について)，日耳 竄: 60巻, 臨時号, 274 頁, 昭 32 (1957). 51) Bö $t$ tcher: Arch. Anat. Physiol., Lpg., p. 372 (1869), (54) 引用. 52) Chilow: Zur Frage über die Ausg. leichung des labyrinthdrucks Zeit. f. Hals-usw. HK : $5: 404$ (1923). 53) Reudinger: Zeit. f. Anat. u. Entwiklungsgesch, Bd 11, (1887). (31) 引 用. 54) Seymour: Observation on the Circulation in the Cochlea. J. Laryng. and otol. : 68: 689 (1954). 55) Shambaugh (1909)，(20) 引用. 56) Guild: The Circulation of the labyrinth. Amer. J. Anat. : 39 : 57 (1927). 57) 河野敏之: 内耳循

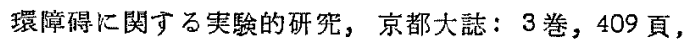

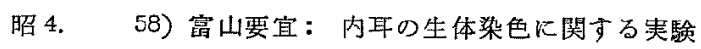
的研究, 解剖誌: 7 卷, 1391 頁, 昭 9. 59) Miyamoto: Experimentelle Untersūchnng über die Schädigūng des Gehörorgans durch die Gift-Wirkūng d. Arzneimittel. Arbeiten aus der Med. Universität Okayama：2：412(1931).60) 尾鈛二郎：

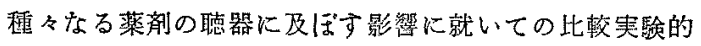
研究, 日耳鼻：43巻，1245頁，昭 12.61 ) 大沢正人：

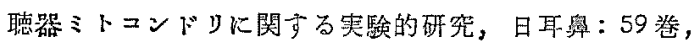
1245 页, 昭 31 . 62) Fieandt, Saxen: Beiträgezur Histologie der Stria vascūlaris und der Prominentia Spiralis bei Saūgern (Hūnd u. Mensch). Z. f. Anat ū Entschlungegesch: 106: 425, (1936). 63) Saxen: Histological Studies of the Endolymph and Resorption in the inner Ear. Acta otolaryng: $40 ; 23$ (1951). 64) Nachlas, Lurie: The Stria Vascularis (Rivewand Observation) Laryngoscope: 61:989, (1951). 65) Francis, Weille: The 
Signification of the Arteriovenous Archades of the spinal lagmient of the cochlea. Ann of otol.: 64: 173 (1955). 66) Smith: Structure of the stria vascularis and spinal prominence. Ann of otol.: 66:521 (1957). 67) 野木敏之：血管条上皮 の笑験細胞学的矿究, 日耳鼻：61替，1174頁，昭 3 . 68) 原田隆宜：内四リンパ循環障碍に関す奏験的硼究，

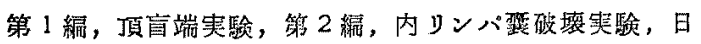
耳邹：62巻，319 頁及び 325 頁，昭 34. 69) 涉谷友

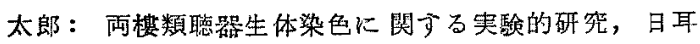
奥：55栬, 707 頁, 昭 27.70) Naftalin and Harrison: Circūlation of lahyrinthine Fluids. Journal. of L. \& O.: 72: 118 (1958). 71) Lempert, Wever and Lawrence: Are the membranous Walls of the endolymphatic labyrinth permeable? Acta otolaryng. Sup 116: 182 (1954).

72). Mygind: Further labyrinthine Studies. Acta otolaryng. Sup. 58: 1 (1948). 73) Mygind: Beiträge Zur physiologische Flüssigkeitssystem des Labyrinth. Arch. ohr-usw. Heilk: 160: 472 (1952). 74) 大沢正

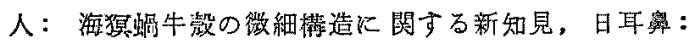
61 巻, 1598 頁, 昭 33. 75) Siebenmann: (31) 引 用. 76) 高森時堆: 聴器の生体色猄攝取, 京都医会 誌，17卷，1072面，大9. 77) 中道吉竟: (20) 引 用. 78) Portmann: L'utisation des Isotopes Radioactifs dans la physiologie des Liquides Labyrinthiques. Acta otolaryng, 44: 532 (1954). 79) Graf ancl poretti: Die Entstehlung der perilymph. prac otorhinolaryng, 12: 351 (1950), 80) 鹿沽政

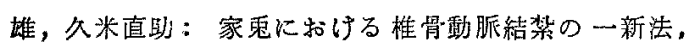
耳奥臨床：20 巻，741 頁，昭 2. 81) 松浦郁夫：5
つ血に因る聴器障碍に関する実験的研䒧，東北医誌：30 巻，583面，昭 17.82$)$ 神岡蕉二：聴器迷路のシニワ ルッマン型組織反応に関する実験的研究,日耳奥：55巻， 317 ，昭 27，83）稻葉節子：内耳と脳腔との関倸に就

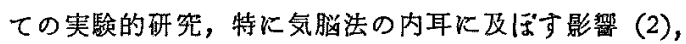
日耳畺：55巻，624面，昭 27.84）山口久雄：膜様 迷路の細胞学的研究, 第 1 編, 内耳組蟣の形態学的研

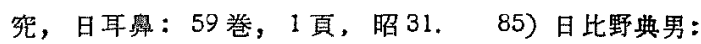

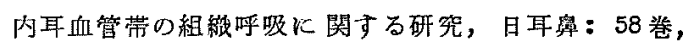
563 頁, 昭 30.86$)$ 大橋和：内耳血管带に観する实 験的研究 (第 2 編)，名古屋医学：第 67 巻，6号，1頁， 昭 28. 87) Meyer: Über die Durchlässigkeit des Endolymphshlauches für Flüssigkeiten. Zeit. f. Laryng. R.O.: 30 : 455 (195i).

擱筆するに臨め御指遵御校閲をいたろ゙いた恩 師後藤修二教授に泳謝し，併さて種々御助言を いたら゙いた三宅弘助教授並びに，研究に便宜を 与夫られた稲沢病院㣠田功院長に感謝する。

本論文の要旨は，1）日本耳鼻咽喉科学会第 3 回中部地方連合会，2）名古屋医学会第 70 回 例会，3）日本耳鼻咽啹科学会東海地方会籍 15 回大会，4）日本耳韨咽喉科学会東海地方会第 153 回例会，5）日本耳嶴咽喉科学会東海地方 会第 154 回例会，6）日本耳䁷咽喉科学会第 4 回中部地方莗合会，7）日本耳鼻咽喉科学会東 海地方会第 16 回大会，8) 日本耳鼻咽喉科学会 東海地方会第 158 回例会，9）日本耳奥咽㗱科 学会第 58 回学術講演会に特いて登表した。

（原槁到着 $=$ 昭和 34.10 .17 日） 